NBER WORKING PAPER SERIES

\title{
ENTREPRENEURIAL SPAWNING: PUBLIC CORPORATIONS \\ AND THE GENESIS OF NEW VENTURES, 1986-1999
}

\author{
Paul Gompers \\ Josh Lerner \\ David Scharfstein \\ Working Paper 9816 \\ http://www.nber.org/papers/w9816
NATIONAL BUREAU OF ECONOMIC RESEARCH
1050 Massachusetts Avenue
Cambridge, MA 02138
July 2003

Seminar participants at the Bank of Italy, Berkeley, Harvard, Stanford, and the University of Wisconsin provided useful comments, as did Rebecca Henderson, Antoinette Schoar, and Noam Wasserman. We thank Harvard Business School's Division of Research and the National Science Foundation for financial support. We are grateful for the research assistance of Jason Breen, Jon Daniels, Sonia Koshy, Robin Lee, Jonathan Man, Oguzhan Ozbas, and Bernard Yoo. We also thank David Witherow of VentureOne and Tracey Boylston of Thomson Delphion for providing us with the data. All errors are own. The views expressed herein are those of the authors and not necessarily those of the National Bureau of Economic Research

(C2003 by Paul Gompers, Josh Lerner, and David Scharfstein. All rights reserved. Short sections of text not to exceed two paragraphs, may be quoted without explicit permission provided that full credit including (C) notice, is given to the source. 
Entrepreneurial Spawning: Public Corporations and the Genesis of New Ventures, 1986-1999 Paul Gompers, Josh Lerner, and David Scharfstein

NBER Working Paper No. 9816

July 2003

JEL No. G2, L2

\begin{abstract}
$\underline{\text { ABSTRACT }}$
This paper examines the factors that lead to the creation of venture capital backed start-ups, a process we term "entrepreneurial spawning." We contrast two alternative views of the spawning process. In one view, employees of established firms are trained and conditioned to be entrepreneurs by being exposed to the entrepreneurial process and by working in a network of entrepreneurs and venture capitalists. Alternatively, individuals become entrepreneurs because the large bureaucratic companies for which they work are reluctant to fund their entrepreneurial ideas. Controlling for a firm's size, patent portfolio and industry, we find that the most prolific spawning firms were public companies located in Silicon Valley and Massachusetts that were themselves once venture capital backed. Less diversified firms are also more likely to spawn new firms. Spawning levels for these firms rise as their sales growth declines. Firms based in Silicon Valley and Massachusetts and originally backed by venture capitalists are more likely to spawn firms only peripherally related to their core businesses. Overall, these findings appear to be more consistent with the view that entrepreneurial learning and networks are important factors in the creation of venture capital backed firms.

Paul Gompers

Graduate School of Business Administration Harvard University, Morgan 483

Soldiers Field Road

Boston, MA 02163

and NBER

pgompers@hbs.edu

David Scharfstein

Sloan School of Management

MIT, Room E52-433

50 Memorial Drive

Cambridge, MA 02142-1347

and NBER

dscharf@mit.edu

Josh Lerner

Graduate School of Business Administration Harvard University, Morgan 395

Soldiers Field Road

Boston, MA 02163

and NBER

jlerner@hbs.edu
\end{abstract}




\section{Introduction}

There is now a large and growing literature analyzing the factors that determine whether entrepreneurs raise venture capital funding (Hellmann and Puri [2000]; Burton, Sørensen, and Beckman [2002]) and the factors that affect the terms of this financing (Gompers [1997], Kaplan and Stromberg [2002]). There is much less understanding of how these venture capital backed entrepreneurs come to be entrepreneurs in the first place. In this paper, we try to fill this gap by examining the factors that lead to the creation of venture capital backed entrepreneurs, a process we term "entrepreneurial spawning."

We contrast two alternative views of the spawning process. In one view, employees of established firms are trained and conditioned to be entrepreneurs by being exposed to the entrepreneurial process and by working in a network of entrepreneurs and venture capitalists. The prolific spawning of entrepreneurial firms by Fairchild Semiconductors and its descendents is a prominent example of "how entrepreneurial learning and networks may function," as Saxenian [1994] writes. Fairchild was founded by eight engineers who left Shockley Semiconductor with $\$ 1.5$ million in venture capital funding from Arthur Rock, one of the earliest (and later most successful) venture capitalists. While the "Treacherous Eight" succeeded as inventors of the first integrated circuit in 1959, the founders and other engineers soon began to leave Fairchild to begin firms of their own. Between 1957 and 1976, at least 23 out of 67 entrants to the semiconductor industry had at least one founder who worked for Fairchild (Braun and Macdonald [1982]), including Advanced Micro Devices, Intel, and National Semiconductor, almost all of which were based in Silicon Valley. 
In this view, individuals already working for entrepreneurial firms, particularly those already backed by venture capitalists and located in hotbeds of venture capital activity—notably Silicon Valley and Massachusetts—may find launching their own venture less daunting than others might. This may be the case for a number of reasons. First, working in such firms exposes would-be entrepreneurs to a network of suppliers of labor, goods, and capital, as well as a network of customers (Saxenian [1994]). Because starting a new venture requires suppliers and customers to make relationship-specific investments before it is guaranteed that the venture will get off the ground, networks can be particularly useful in alleviating this chicken-and-egg problem (Hellmann [2002]). Second, would-be entrepreneurs learn how to found companies by participating in the entrepreneurial process alongside other, more experienced entrepreneurs. Finally, individuals with a higher taste for risky activities may have already found their way to entrepreneurial firms, consistent with the sorting processes hypothesized by Jovanovic [1979], Holmes and Schmidt [1990] and Gromb and Scharfstein [2002]. We refer to this depiction of entrepreneurial spawning as the "Fairchild view."

An alternative view of the entrepreneurial spawning process is that individuals become entrepreneurs because the large bureaucratic companies for which they work are reluctant to fund their entrepreneurial ideas. The most prominent example of this is Xerox, which developed many of the key technologies underlying the personal computer, but which failed to commercialize these technologies (summarized in Hunt and Lerner [1995]). In 1969, Xerox chief executive Peter McColough commissioned the firm's head of research to build a new laboratory to provide the company with the technology to move the firm from being the leading office copier company to being the dominant 
supplier of information-intensive products (Chesbrough [2002]). The Palo Alto Research Center (PARC) was formed to house this group in 1970. The firm hired outstanding researchers for this new technical initiative, including physicists, mathematicians, materials scientists, computer system architects, and software engineers. PARC proved to be enormously fertile, inventing such technologies as laser printing, the Ethernet, the graphical user interface, and personal distributed computing. Despite appeals by PARC leaders to invest in commercializing these innovations, the firm's Rochester, New Yorkbased executives resisted such expenditures. Instead, the vast bulk of the value from these inventions was captured by employees who left Xerox to found companies such as Adobe Systems and 3Com as well as licensees such as Apple Computer.

There are at least three reasons that large, established firms might be more prone to spawn entrepreneurial ventures. We will refer to this as the "Xerox view" of entrepreneurial spawning. First, it may be that firms are incapable of responding to radical technological changes that upset the established ways of organizing their businesses. Christensen [1997], perhaps the most visible proponent of this view, has written about the failure of companies to capitalize on "disruptive technologies":

Why was it that firms that could be esteemed as aggressive, innovative, customer-sensitive organizations could ignore or attend belatedly to technological innovations with enormous strategic importance? ... Finding new applications and markets for new products seems to be a capability that each of these firms exhibited once, upon entry, and then apparently lost. It was as if the leading firms were held captive by their customers, enabling attacking entrant firms to topple the incumbent industry leaders each time a disruptive technology emerged (Christensen [1997], p. 24).

Henderson [1993] presents evidence of the organizational incapacity of firms to respond to technological change. Using data from the semiconductor photolithography industry, 
she shows that incumbents were consistently slower than entrants in developing and introducing new technologies.

A second, related reason why large, established companies may spawn more is that high-level managers at these firms are incapable of evaluating these entrepreneurial opportunities because they fall outside the company's core line of business. Assessing these opportunities may also require the analysis of "soft information," which hierarchical organizations may have a hard time doing (Stein [2002]; Berger, et al. [2002]). Moreover, the internal capital market tends to favor established lines of business over less established, but perhaps more promising, businesses (Scharfstein [1998]; Scharfstein and Stein [2000]). These arguments suggest that a considerable amount of entrepreneurial spawning should come from large established firms, where these problems are presumably most severe.

Finally, it is also possible that the level of entrepreneurial spawning would be high among these firms not because of any sort of inefficiency at these firms, but rather because these firms wisely choose to focus on their core business or "core competence." The wisdom of focusing on one's "core competence," has been a mainstay of management consulting since the 1980s. It is also supported by the findings that:

- diversified firms tend to trade at a discount to a portfolio of comparable focused firms (Berger and Ofek [1995]);

- firms that diversified excessively during the 1960 s and 1970 s were more likely to be acquired and broken up in the subsequent two decades (Mitchell and Lehn [1990]); and 
- when firms diversified into unrelated businesses, the productivity of their existing businesses declined (Schoar [2002]).

Thus, in this view, even though good entrepreneurial ideas might be germinated at these firms, management wisely chooses not to develop them because it would do more harm than good to their core businesses.

This paper is an empirical exploration of the Fairchild and Xerox views of the entrepreneurial spawning process. To analyze these perspectives on spawning, we assemble a database of employees who leave public companies to start venture capital backed firms during the period 1986-1999. From these data, we are able to calculate the spawning levels of public companies. We then relate these spawning levels to firm characteristics in a cross-sectional analysis and examine how these spawning levels change over time for particular firms.

Controlling for firm size, patent portfolio, and industry, we find that the most prolific spawning firms from 1986 to 1999 were public companies located in Silicon Valley and Massachusetts that were once venture capital backed themselves. These effects are substantial: being located in Silicon Valley increases the spawning level by almost 38\%; companies in Massachusetts have a $23 \%$ higher spawning level; and companies that were once venture capital backed have a $23 \%$ higher spawning level.

Diversified firms appear to spawn less, not more. Firms focused in one segment have spawning levels $19 \%$ higher than those operating in multiple segments. Moreover, after controlling for the quantity, quality, and originality of patents that firms have in the areas of principal interest to venture capitalists (computers and communication as well as drugs and medical), the existence of other types of patents in the portfolio (e.g., 
mechanical patents) tends to reduce a company's spawning level. This result is inconsistent with the notion that more diversified firms will spawn more. Our findings appear to be more consistent with the notion that diversified firms are less entrepreneurial and thus less prone to have the sorts of people who would have the inclination, ability, or skills to start new venture capital backed firms.

The penultimate empirical section of the paper examines how spawning levels change over time for firms. Thus, we construct a panel of annual spawning levels for firms with patents in areas of interest to venture capitalists. When we use firm fixed effects in our regression analysis, we find that firm spawning levels are lower when a firm's past sales growth is high relative to the firm's mean level of growth. We interpret this finding as indicating that when firms are growing rapidly, employees choose to stay at their firms (and perhaps develop their entrepreneurial ideas internally) because they perceive the rents from doing so to be high. When growth slows, however, employees are more prone to seek entrepreneurial opportunities outside the firm.

One competing interpretation of our findings is that venture capital backed firms in Silicon Valley and Massachusetts with a history of venture capital backing have high spawning levels not because of entrepreneurial learning, networks, or attributes, but simply because they have technologies and operate in businesses that are of more interest to venture capitalists in the first place (as, for instance, the tabulations in Kortum and Lerner [2000] suggest). While this remains a possible explanation, it is worth noting that we have controlled extensively for patent characteristics (quantity, class, quality, and originality) and industry. Thus, if high spawners simply function in fields of greater 
relevance to venture capitalists, they must do so in a way that is neither observable to us nor captured by our patent and industry controls.

As a further check to see that our results are not driven by technology differences, we examine the extent to which venture capital backed start-ups pursue businesses related to those of the firms from which they are spawned. If technology differences underlie our results, we would expect to see more related spawning from the high spawners. However, this is not what we observe in our empirical analysis. We find, instead, that firms located in Silicon Valley and Massachusetts with prior venture capital backing spawn less related businesses.

This finding also sheds some light on the causes of entrepreneurial spawning. The results do not appear to be consistent with Xerox-type spawning because we would expect less related spawning from large, established firms for the reasons discussed above, i.e., the inability of the firms to evaluate technologies outside their core business or the commitment on the part of these firms to focus on their core business. Instead, the findings appear to be more consistent with the view that these firms are unable or unwilling to take advantage of entrepreneurial opportunities in their core business (perhaps because of fear of cannibalization). By contrast, the high spawners in Silicon Valley and Massachusetts are more prone to spawn outside their core and would appear to be capitalizing on opportunities in their core lines of business.

The rest of the paper is organized as follows. Section I describes the construction of the data set and summarizes the data. The analysis is presented in Section II. Section III concludes the paper, discusses some implications of our findings, and highlights other research opportunities in this area. 


\section{Constructing the Data Set}

The core data for the analysis come from VentureOne. VentureOne, established in 1987, collects data on firms that have obtained venture capital financing. Firms that have received early-stage financing exclusively from individual investors, federally chartered Small Business Investment Companies, and corporate development groups are not included in the database.

The companies are initially identified from a wide variety of sources, including trade publications, company Web pages, and telephone contacts with venture investors. VentureOne then collects information about the businesses through interviews with venture capitalists and entrepreneurs. The data collected include the identity of the key founders (the crucial information used here) as well as the industry, strategy, employment, financial history and revenues of the firm. Data on the firms are updated and validated through monthly contacts with investors and firms.

For the purposes of this analysis, we examine the founders and initial executive officers (henceforth referred to as "entrepreneurs") that joined firms listed in the VentureOne database during the period from 1986 and 1999. ${ }^{1}$ Typically, the database reported the previous affiliation and title (at the previous employer) of these entrepreneurs,

\footnotetext{
${ }^{1}$ We did not include events in earlier periods because of concerns about selection biases. VentureOne has "back-filled" data on entrepreneurial firms through the early 1980s, but firms that did not survive until 1987 were not added to the database. At the time this study was initiated, the 2000 and 2001 data were substantially less complete than the other years due to lags in identifying and surveying firms.
} 
as well as the date they joined the firm. ${ }^{2}$ In some cases, however, VentureOne did not collect this information. In these cases, we attempt to find this information by examining contemporaneous news stories in LEXIS-NEXIS, securities filings, and web sites of surviving firms. ${ }^{3}$ We believe this data-collection procedure may introduce a bias in favor of having more information on successful firms, but it is not apparent to us that it affects our analysis.

Table I summarizes the population of entrepreneurs and their venture capital backed start-up firms. First, the table presents the number of entrepreneurs that joined new venture capital backed companies in the VentureOne database by the year that they joined those venture-backed firms, as well the number of new venture capital backed firms that these entrepreneurs joined in each year. We also list the number of venture capital backed technology companies. We then present the number of entrepreneurs who held at least one of three key titles in the new company-CEO, president, and chief technical officer (CTO) - as well as the count of entrepreneurs who left firms that were publicly traded. Finally, we report the share of entrepreneurs that were from entities that were publicly traded at the time of their departure.

Two observations should be highlighted from the summary statistics. First, the level of activity has risen over the period, reflecting the more general growth of the venture

\footnotetext{
${ }^{2}$ We code the entrepreneur as being spawned from the most recent company for which he worked, even though he may have a wealth of experience working at other types of companies.

${ }^{3}$ When we were unable to ascertain the year in which the individual joined the firm, we used the year in which the firm was formed, which was the modal answer in cases where we had complete data. This approach does introduce some empirical difficulties, as we discuss below.
} 
capital industry over these years. ${ }^{4}$ The number of entrepreneurs joining venture capital backed start-ups increases from 483 in 1986 to 1717 in 1999. Similarly, the number of distinct venture capital backed firms represented in the sample increases from 218 in 1986 to 799 in 1999 . Second, the share of entrepreneurs that emerge from publicly traded firms is significant. The first measure we report calculates the share as a percentage of all entrepreneurs. This measure suggests that there has been an increase of about $40 \%$ over this period in the share of entrepreneurs coming from public companies (from $30 \%$ to $42 \%$ of the entire sample of entrepreneurs). There are many entrepreneurs, however, for which the database reports no prior work history. If one excludes these entrepreneurs from the calculation, the share of entrepreneurs coming from public companies appears more stable, averaging approximately $45 \%$ per year. The difference in these findings is probably attributable to the more complete reporting of prior work histories in later years.

The data on entrepreneurs are linked to information on the companies that spawned them. In particular, we determine whether the entrepreneur had previously been employed at a publicly traded firm in the United States, and, if so, we link it to the appropriate firm in the Compustat and Center for Research into Securities Prices (CRSP) databases. We also identify the spawning firm's patents (and their characteristics) using the National Bureau of Economic Research's (NBER) Patent Citations Data File (summarized in Hall, Jaffe, and Trajtenberg [2001]). This database links patent data from the U.S. Patent Office to

\footnotetext{
${ }^{4}$ The reader may be puzzled that the volume of spawned venture capital backed start-ups falls in 1999, a record year for venture capital activity. This decline occurs because the years reported are those where the entrepreneurs joined the new firms, not the year of first venture capital financing. Thus, even though many more entrepreneurs may have joined start-ups in 1999, it is likely that a smaller percentage of them were later funded by venture capital because of the plunge in the NASDAQ in April 2000 and the subsequent drop in overall venture capital funding.
} 
Compustat (as it was comprised in 1989). We add links for companies listed in Compustat after $1989 .^{5}$

Table II lists the firms and industries that were most active in spawning new firms. Panel A lists the 48 publicly traded corporations that spawned ten or more entrepreneurial teams during the sample period. (Multiple individuals departing to establish a firm are regarded as a single team). Panel B describes the top three-digit Standard Industrial Classification (SIC) codes in which the most spawners operated. (Each firm is assigned to one three-digit SIC code, based on the primary industry assigned in Compustat.) The dominant importance of firms in the software, computer and office equipment, and drug industries is apparent. The concentration of entrepreneurs spawned from public firms in these industries closely mirrors the overall investment pattern of the venture capital industry. It is not surprising that the venture capitalists would finance entrepreneurs with relevant technology experience.

Table III compares spawning firms to non-spawning firms. We take averages for each company that ever spawned a venture capital backed start-up in the VentureOne database during these years: i.e., those that spawned at least one entrepreneur over the time period. We contrast these firms to those that spawned no venture capital backed firms. For the purposes of interpreting our later results, we report summary data only on those firms that end up in our basic regression analysis.

\footnotetext{
${ }^{5}$ Because there are a very large number of companies listed in the patent database, it was not feasible to scan the entire database for possible links to Compustat. Thus, we listed all companies in the patent database with at least two patents in the computers and communication and medical and drugs patent categories and narrowed our search of public companies to this subset of patent holders.
} 
The tabulation reveals that spawning firms tend to be significantly larger than nonspawners. For instance, the median spawning firm has $60 \%$ higher sales, $90 \%$ greater assets, and $170 \%$ more employees. Tobin's Q is calculated as the ratio of the market value of the firm to the book value of its assets, following the procedure delineated in Kaplan and Zingales [1997]. Because the distribution of Tobin's Q has a dramatic rightward skew, we report winsorized versions of this measure, cutting off the distribution at a $Q$ of 10 , roughly corresponding to the $99^{\text {th }}$ percentile. The mean $\mathrm{Q}$ of spawning companies (2.75) is somewhat higher than the mean Q of non-spawning firms (2.54). The difference in the medians is much larger: 2.18 versus 1.71 . The average EBITDA to assets ratio is not appreciably different across the two sub-samples but sales growth is considerably higher among the spawning firms. ${ }^{6}$

In addition to looking at differences in the financial performance of spawning and non-spawning firms, we also tabulate whether the headquarters of these firms are in Silicon Valley or Massachusetts. Prior venture capital backing is determined by linking the companies to the Venture Economics database of venture capital financings (discussed in Gompers and Lerner [1999]), and then supplemented with the annual listing of venture capital backed IPOs in Venture Capital Journal. Following Saxenian [1994], we define Silicon Valley as California's Alameda, San Mateo, and Santa Clara counties. Although the hub of start-up activity in Massachusetts is around Route 128 (Middlesex County), the state is small enough that it is not meaningful to make distinctions among the counties of Massachusetts. We determine the headquarters' location from Compustat. Spawning firms

\footnotetext{
${ }^{6}$ These measures are also winsorized. In the case of EBITDA to assets we cut off any ratios below -0.5 and above 0.5 and in the case of sales growth we cut off any rates above 10.
} 
are much more likely to have been venture capital backed themselves (35.5\% vs. $12.2 \%)$ and to be located in the hubs of venture capital activity, Silicon Valley and Massachusetts.

The table also lists information on the degree of focus of the spawning and nonspawning firms. We consider a firm focused if it reports just one industry segment in its filings with the Securities and Exchange Commission. ${ }^{7}$ Spawning firms tend to be more focused even though they are substantially larger.

Not surprisingly, spawning firms have considerably more patents over the period from 1980 to 1999 , particularly in patent classes that are most relevant to venture capital, i.e., patents with a primary assignment to category 2 , "Computers and Communications," or category 3, "Drugs and Medical," using the classification scheme in the NBER data file.

Finally, the table reports information on the average quality and originality of patents in categories 2 and 3 for these companies. The standard measure of patent quality (see the extended discussion in Jaffe and Trajtenberg [2002]) is the number of citations the patent receives. We use this citation measure of quality, adjusting for the year in which the patent was granted and the sub-category of the patent. ${ }^{8} \quad$ Thus, our quality measure is the

\footnotetext{
${ }^{7}$ There are a number of limitations of this focus measure. One is that firms have discretion in what businesses they choose to lump together into a business segment. Thus, some single-segment firms that pool a number of businesses into one segment may be no more focused than a multi-segment firm that breaks them out. Another limitation is that some of the multiple segment firms may have quite related businesses across different segments. Our measure takes no account of those relationships. Despite this measurement error, it is likely that on average the firms we categorize as focused will indeed be more focused than the other firms in the sample.

${ }^{8}$ The NBER database includes four subcategories for Computers and Communications: "Communications, "Computer Hardware and Software," "Computer Peripherals," and "Information Storage." There are four sub-categories for Drugs and Medical: "Drugs," "Surgery and Medical Instruments," "Biotechnology," and "Miscellaneous."
} 
firm fixed effect in a regression of a patent's citations on a set of dummy variables for the year in which the patent was granted and the patent sub-category. The table indicates that the average patent quality of spawning firms is higher than that of non-spawning firms.

Recent research (summarized in Jaffe and Trajtenberg [2002]) has highlighted the importance of the measure of patent originality. A patent is considered more original if it cites patents across more patent categories, as it is more likely to synthesize knowledge across a variety of disciplines. We use this measure reported in the NBER Patent Citations Data File, again adjusting for the granting year of the patent and the patent's sub-category. The table shows that the average originality of patents held by spawning firms is lower than that of non-spawning firms.

\section{Analysis}

We present the results here in five sub-sections. We start in sub-section II.A by analyzing the factors that affect the total number of venture capital backed start-ups that public companies spawn over the entire sample period, 1986-1999. In the next two subsections, II.B and II.C, we examine the extensive and intensive margins of spawningi.e., the factors that determine whether a firm spawns at all and the factors that determine how much spawning a firm undertakes conditional on spawning at least one firm. We then examine in sub-section II.D whether the factors that explain overall spawning levels explain spawning levels on a yearly basis. In this sub-section, we also look at the annual spawning levels in a model with firm fixed effects. Thus, we are able in this part of the paper to examine the time-varying characteristics that affect whether a firm's spawning 
level is above or below its own mean. In subsection II.E, we examine the extent to which the activities of the spawned firms are related to their parents.

\section{A. The Determinants of Total Spawning}

In this section, we analyze the factors that affect the total number of venture capital backed companies spawned by public companies during the sample period 19861999. One issue that we face from the outset is that some firms will have very little spawning activity simply because they specialize in areas that are of little interest to venture capitalists. Indeed, historically, more than $80 \%$ of venture capital disbursements have gone to firms in the information technology and health-related fields. Thus, for the bulk of the analysis, we restrict our analysis to firms who were awarded at least one patent between 1981 and 1999 in NBER patent categories 2 (computer and communications) or 3 (drugs and medicine), which correspond to areas of greatest interest to venture capitalists.

As the dependent variable, we use the logarithm of the number of venture capital backed start-ups that the firm spawns over the sample period (plus the number one to avoid dropping non-spawning firms). When more than one person leaves a given company in a given year to form a particular firm, we still count it as one firm that was spawned. In some of the analyses, we look only at spawning of start-ups in technology intensive businesses for which the patents in categories 2 and 3 are most relevant. As shown in Table I, these spawned firms account for roughly two-thirds of the companies spawned in a given year. 
We start by looking at overall spawning because of our inability to identify the spawning date with certainty for every venture capital backed company. In many cases, VentureOne does not report the date on which the entrepreneur joined the start-up. In these cases, we tried to fill in this information from publicly available information, but in many of them, we were unsuccessful. When we could not find the information from other sources, we used the founding date of the start-up. There are, however, a number of cases in which the founding date of the company precedes the founding date of the public company, indicating that the entrepreneur most likely joined at a later time. These observations are dropped from the analysis when annual spawning levels are analyzed. This tends to disproportionately reduce the measured spawning levels of young public companies. Of course, looking at overall spawning levels has its own limitations, the most important of which is that it does not allow us to examine the time dynamics of spawning. Since there is no perfect solution to this problem, we analyze the determinants of total spawning levels here and annual spawning levels in sub-section II.D below.

The first column of Table IV reports the results of a cross-sectional regression in which the dependent variable is the log of a firm's total spawning. The mean of this variable is 0.482 , indicating that the average firm spawns 0.619 firms between 1986 and 1999. The regressors in this analysis are: (1) the log of the total number of patents the firm was granted between 1981 and 1999 in each of the six NBER patent categories (as described in Hall, Jaffe, and Trajtenberg [2001]); (2) the mean of logarithm of the firm's assets over the sample period expressed in 1996 dollars; (3) the mean ratio of EBITDA to assets; (4) the mean annual growth of real sales; (5) the mean of annual Q; (6) a dummy variable that equals one if the firm was venture capital backed; (7) separate Silicon 
Valley and Massachusetts dummies; (8) the mean of the firm's focus dummy; (9) the quality of patents in categories 2 and 3; and (10) the originality of the patents in categories 2 and 3. Because the firms are in the sample for different numbers of years, we also include a set of dummy variables for each year the firm is in the sample. The tstatistics are based on heteroskedasticity-adjusted standard errors that allow for nonindependence of observations across firms within the same 2-digit SIC code.

Not surprisingly, the coefficients of the patent quantities in categories 2 and 3 are positive and highly statistically significant. The coefficient indicates that the elasticity of spawning with respect to patenting in category 2 is 0.235 and that the elasticity in category 3 is 0.141 . It is noteworthy also that this elasticity is less than one; doubling a company's patents generates significantly less than twice as many spawned entities. There may be several explanations of this finding. First, not all businesses are based on patents and technological know-how; patents may be irrelevant for these spawned entities. Second, many patents may have no immediate practical business value. If larger firms with more patents are more likely to have such patents (perhaps because they have internal patent departments that reduce the cost of applying for patent awards, and thus make it worthwhile to apply for more marginal awards), the incremental impact of a patent on spawning activity could be lower. A third possibility is that some patenting may be an attempt to limit the extent to which employees take their ideas and start new ventures. Finally, to the extent that we have included other measures of size, such as the logarithm of real assets, these variables may be picking up some of the effect of an increase in patenting. 
Interestingly, the coefficients on the other four patent categories are all negative and, in the case of mechanical patents (category 5) and other patents (category 6), they are statistically significant. This finding suggests that having research activities outside of the main venture capital related areas reduces the level of spawning. This is not consistent with the Xerox view that spawning is a consequence of corporate bureaucracy. It is, however, consistent with the Fairchild view to the extent that firms operating in multiple areas of research tend to be less entrepreneurial in style and attract a less entrepreneurial type of employee. We discuss this and related findings later in this section.

The table also indicates that firms with more assets spawn more firms, which is not surprising given that the dependent variable is not size adjusted. There is no statistically significant link between spawning and EBITDA over assets, nor with oneyear real sales growth. High Q firms do, however, spawn more. There are many potential explanations for this finding. One plausible explanation is that firms have high $\mathrm{Q}$ because they are expected to develop new businesses. The ideas for these new businesses are generated by the firm's employees and some of them may choose to develop the ideas on the outside, backed by venture capital.

The coefficient of the venture capital dummy is positive, large and highly statistically significant. The estimate of 0.264 indicates that, all else equal, public companies that were once venture capital backed spawn $26.4 \%$ more firms than those that were not venture capital backed. The coefficient of the Silicon Valley dummy indicates that public companies based in Silicon Valley spawn 37.7\% more firms than those based outside the two hubs of venture capital activity. The coefficient estimate on the 
Massachusetts dummy is also large and statistically significant; while smaller than the effect of being in Silicon Valley, the effect is comparable in size to that of being venture capital backed.

The result that venture capital backed firms spawn more is consistent with the Fairchild view of spawning. In this view, employees of venture capital backed firms learn how to be entrepreneurs through the experience of working in an entrepreneurial environment. They may also have greater exposure to the network of suppliers of goods, capital, and labor, as well as customers. Furthermore, employees that select into venture capital backed firms may be less risk averse, and thus more willing to accept the risks associated with starting a new company. While it is difficult to determine the precise mechanism through which employment at a venture capital backed firm affects the amount of spawning, the effect is quite strong in the data. The finding does not appear to be consistent with the alternative Xerox view of spawning.

The positive effect of being located in Silicon Valley and Massachusetts is also consistent with the Fairchild view. In both regions, employees have a closer connection to a network of suppliers of goods, capital and labor that is critical to the creation of a new enterprise. Saxenian [1994] argues that being located in a region with other small entrepreneurial firms makes it easier to find companies that are willing to supply critical inputs. She argues that this effect is stronger in Silicon Valley than in Massachusetts because the latter region tends to have larger, more vertically integrated firms. Although we estimate a larger effect in Silicon Valley than in Massachusetts, it would be a stretch to say that we have confirmation of Saxenian's claim. 
We also find that a firm's average level of focus is positively related to the extent of its spawning. The estimated effect is also quite large. A firm that is focused throughout the sample period spawns $20 \%$ more than a company that is diversified throughout. This finding appears at odds with the view that spawning is a response to bureaucratic rigidities in large, technology-intensive firms. The result appears more consistent with the Fairchild view.

The regression results also indicate that older public companies spawn fewer venture capital backed start-ups. The estimated elasticity of $5.8 \%$ is small. Given the imprecision with which we measure firm age, these results need to be interpreted with some caution.

Finally, the regression includes measures of patent quality and originality. Firms with higher quality patents in categories 2 and 3 appear to spawn more, while those with lower average originality appear to spawn less. The coefficient of patent quality is statistically significant, while the coefficient of patent originality is not. An increase from the $25^{\text {th }}$ percentile of quality to the $75^{\text {th }}$ percentile - an increase of 6.3 adjusted citations-leads to an increase of $2.8 \%$ in the level of spawning, a small effect. Like the age effect, the estimated effect of patent quality is rather unimpressive.

The second set of regressions in Table IV uses spawning in technology industries as the dependent variable. We find the same basic patterns of results here as we did in the regression with overall spawning. The last two columns repeat the first two but add industry dummies for two-digit SIC codes. The key findings are unaffected: the coefficients of the venture capital, Silicon Valley, and Massachusetts dummies and the coefficient of average focus all remain positive and statistically significant. The 
magnitudes of the coefficients also change very little. Mean Q, age, and patent quality are no longer statistically significant, though their magnitudes change very little.

In unreported regressions, we examine the influence of repeat entrepreneurs. "Serial entrepreneurs," who work at multiple entrepreneurial firms, are said to be important in many industries. It is reasonable to worry that serial entrepreneurs drive our results that firms based in Silicon Valley and Massachusetts and backed by venture capitalists spawn more. That is, these firms many not teach their employees how to be entrepreneurs or expose them to networks, or even select for entrepreneurial types. Instead, firms with these characteristics may tend to be younger and more likely to have been founded in the recent past by entrepreneurs. These entrepreneurs may then leave then to start other firms, leading to the appearance that these firms are more prolific spawners.

We thus repeat the analysis, dropping cases where an entrepreneur had been involved with a previous venture-backed firm. To do this, we create an identifier for each entrepreneur, researching the sources noted above to determine whether a "Jim Joyce" and a "James Joyce" in the VentureOne database are really the same person. In all, the elimination of repeat entrepreneurs leads to the elimination of $9.7 \%$ of the observations, where the entrepreneur was involved as a founder or key officer in a previous venture-backed firm. Of the repeat entrepreneurs in the sample, $83 \%$ are involved with two firms, $13 \%$ with three, $3 \%$ with four, and less than one percent with five or more firms.

The deletions have little impact on the results. Neither the magnitude nor the statistical significance of the key results presented in Table IV changes. Similarly, when 
we repeat the analyses reported in later tables, the deletion of the repeat entrepreneurs has little impact.

\section{B. The Characteristics of Firms that Spawn}

In the sample of 1370 companies that patent in categories 2 and 3, 515 companies spawn at least one venture capital backed firm and 855 spawn none. What are the factors that determine whether a firm spawns at least one firm? To address this question, we report the results of regressing a dummy variable that takes the value one if the firm spawns at all on the same set of regressors as those reported in Table IV. Although we report the ordinary least squares estimates in Table V, the logit results are substantively similar.

Not surprisingly, firms with more patents in categories 2 and 3 are more likely to spawn a venture capital backed start-up. A firm with only one patent in category 2 (the $25^{\text {th }}$ percentile of patent quantity) has a $33.5 \%$ chance of spawning a venture capital backed start-up, whereas a firm with 9 patents in category 2 (the $75^{\text {th }}$ percentile) has a $54.6 \%$ chance of spawning a venture capital backed start-up. The estimated effect for patents in category 3 is similar in magnitude. Patenting in the other patent categoriesparticularly in categories 5 and 6-tends to reduce the probability of spawning.

The estimated effects of the critical variables of interest-prior venture capital backing, location, and focus - are all large and statistically significant. The predicted probability of spawning any start-up is $20.2 \%$ higher for venture capital backed public companies than for firms that were not venture capital backed. The empirical model predicts that non-venture capital backed public firms have a $33.0 \%$ probability of 
spawning at least one company, while a venture capital backed public company has a $53.1 \%$ chance of spawning such a firm. The estimated effects are similar in magnitude for firms located in Silicon Valley and Massachusetts. Firms located outside of either have a $34.7 \%$ chance of spawning at least one start-up, while a public company located in Silicon Valley has a $51.2 \%$ chance of spawning a start-up and one located in Massachusetts has a $48.4 \%$ chance of spawning a start-up.

The estimated effect of the focus variable is somewhat smaller than those of location and prior venture capital backing. A firm that is focused throughout the sample period has a $51.8 \%$ chance of spawning at least one start-up, while a firm that was diversified throughout the sample has a $43.4 \%$ chance of spawning a start-up. In interpreting the magnitude of the focus coefficient, however, one has to keep in mind that the regression also includes the number of patents outside of categories 2 and 3, which also measures the degree of focus. Indeed, if one excludes the quantity of patents outside of categories 2 and 3, the estimated coefficient of average focus doubles in magnitude and is highly statistically significant in all specifications.

With respect to patent characteristics, patent quality appears to be significantly and positively related to spawning at least one company, while the effect of originality is negative albeit statistically insignificant.

The second column of Table $\mathrm{V}$ repeats this specification for spawning of technology intensive businesses. The results are essentially unchanged. The last two 
columns add 2-digit SIC code industry dummies. The estimated effects change little across specifications, though patent quality is no longer statistically significant. ${ }^{9}$

\section{The Intensity of Spawning}

In this section, we examine the intensity of spawning, conditional on the firm spawning at least one venture capital-financed firm. Table VI re-estimates the specifications in Table IV for the 515 companies that spawn at least one start-up. The main difference between the coefficients estimated in Table IV and those estimated in Table VI is that, although the estimated coefficient of the venture capital dummy is positive, its magnitude is small and statistically insignificant. Thus, one might conclude that prior venture capital backing affects whether a company spawns, but not how much it spawns conditional on spawning.

The estimated effects of location continue to be large, though the coefficient estimate of the Massachusetts dummy is now estimated imprecisely, perhaps because the sample size is so much smaller now. The coefficient of focus is also positive and borderline statistically significant at the $5 \%$ confidence level. The estimated effect of quality is also positive and statistically significant. None of these effects change substantially when we restrict the dependent variable to the spawning of high-tech firms (column 2) and add industry dummies (columns 3 and 4).

\footnotetext{
${ }^{9}$ Patent quality in categories 2 and 3 appears to be higher if the company patents little outside those categories. Thus, the negative coefficients of patenting outside categories 2 and 3 may proxy in part for poor patent quality in categories 2 and 3. Excluding the patent quantities in categories other than 2 and 3 increases the coefficient of patent quality, which becomes highly statistically significant.
} 


\section{The Determinants of Annual Spawning Levels}

In this sub-section we analyze the determinants of spawning on an annual basis. As discussed above, measuring annual spawning is imprecise given the data we have because in some cases we do not know when the entrepreneur joined the start-up. When we do not have this information, we assumed that it occurred at the founding of the startup. If the start-up is founded before the spawning company goes public, then the observation is dropped from the sample. This approach means that we tend underestimate to a greater extent the number of spawned entities from companies that have gone public more recently. With this caveat in mind, we present the results of pooled cross-section/time series analysis in Table VII and a firm fixed effect analysis in Table VIII.

We observe the same basic pattern of results in the first column of Table VII. Prior venture capital backing, a Silicon Valley or Massachusetts headquarters, and focus are all positively related the annual spawning levels. The effects are somewhat attenuated by including industry dummies and by limiting the spawning to those in technology-intensive industries as shown in columns 2 and 3 of Table VII.

The last column of Table VII reports the result of the between estimator: regressing firm average annual spawning levels on firm averages of the regressors. This approach is similar to the approach taken in Table IV, but relies on the more imprecise measure of annual spawning as opposed to cumulative spawning. Although the results are all consistent with those observed in Table IV, the coefficients are generally more imprecisely estimated in Table VII. 
Table VIII reports estimates of a regression equation with firm fixed effects. We cannot, of course, estimate the effects of the time-invariant factors such as prior venture capital backing and location. Thus, we include only those variables that change over time. The main question that we can address with this approach is whether firms tend to spawn more when their performance and growth are relatively good or when they diminish. There are two alternative views. On the one hand, spawning may be higher during relatively good times as employees are exposed to more entrepreneurial opportunities. On the other hand, when growth slows or performance weakens one might expect employees to be more aggressive in pursuing outside entrepreneurial opportunities as the value of remaining at the company falls.

Table VIII shows that spawning is unrelated to Q and the EBITDA measure, but it is negatively and significantly related to lagged 3-year sales growth. The estimated coefficient, however, is small. The model implies that an increase in sales growth from the $25^{\text {th }}$ percentile to the $75^{\text {th }}$ percentile reduces the log quantity of spawning from 0.089 to 0.085 , a change of just $4.6 \%$. It is difficult to determine whether the effect is genuinely small or is small because of the significant measurement error in calculating annual spawning levels. In either case, however, the results appear to be consistent with the view that employees leave firms not at the peak of their growth rates, but instead when growth rates have fallen, i.e., employees pursue entrepreneurial opportunities outside their firms when the rents from staying at the firm are diminished.

The regression also includes the logarithm of age and the firm focus measure. Spawning appears to decline as a firm ages; the coefficient is significant at the $10 \%$ confidence level. The coefficient on the focus variable is positive, consistent with our 
earlier cross-sectional findings, but the estimated effect is statistically insignificant. In this analysis with firm fixed effects, we can only identify the effect of focus through changes in this variable. To the extent that focus changes little over time, the empirical test does not have much statistical power.

The remaining columns of the table examine slightly different specifications. The second column looks at spawning in high-tech industries. We continue to observe a negative relationship between spawning and sales growth. The third column includes two alternative measures of sales growth: mean industry sales growth over the prior three years and firm-specific deviations from mean sales growth. The results indicate that it is the firm-specific component of sales growth that drives the relationship to spawning.

One might be concerned that what is driving the sales growth results is that firms with large reductions in sales or those that go bankrupt are laying off workers, some of whom find new jobs and some of whom start new companies. If this were true we would expect to see all of the results coming from an increase in spawning when sales drop and not from a decrease in spawning when sales rise. To examine this possibility, we replace the continuous measure of sales growth with dummy variables for two regions of sales growth: sales growth greater than the $75^{\text {th }}$ percentile of sales growth and sales growth less than the $25^{\text {th }}$ percentile of sales growth. The inter-quartile range is excluded so the estimated coefficients are measured relative to this region of sales growth. The results indicate that moving out of the highest quartile of sales growth is associated with significantly greater spawning and that moving from moderate sales growth to the lowest quartile of sales growth is also associated with the more spawning. Though the magnitude of these coefficients is roughly the same, only the coefficient on the high sales 
growth dummy is statistically significant. This result is inconsistent with the hypothesis that spawning is generated by layoffs.

\section{E. Relatedness of Start-up to Parent}

This section examines the extent to which venture capital backed start-ups enter businesses that are related to those of the firms from which they are spawned. We undertake this analysis for two reasons. First, we want to see whether our key findings are driven by unobserved differences in the technologies of the firms that spawn many new ventures and those that spawn relatively few new ventures. For example, one of our main findings above is that public firms based in Silicon Valley or Massachusetts are more likely to spawn new firms, as are public firms that were themselves once venture capital backed. This may simply be because firms in these regions and with prior venture capital backing have technologies that are of more interest to venture capitalists. If, however, we find that these high spawners tend to spawn firms with technologies that are less related to their own technologies, it would cast some doubt on this explanation.

The second reason to study the relatedness of the start-up to its spawning parent is that it can shed light on the causes of spawning. Recall that in the Xerox example, much of the spawning emanated from the Palo Alto Research Center, a group that was distant from corporate headquarters and was pursuing technologies outside Xerox's core business. In this view, spawning occurred because headquarters was out of touch with its peripheral businesses. This example would imply that Xerox-type firms-large, diversified corporations headquartered outside the main regions of venture capital activity 
and with no prior link to venture capital — should be more likely to spawn outside their core line of business.

To investigate the relatedness of start-ups to their spawning parents, we first need a measure of relatedness. One possibility is to use industry codes of the start-up and the spawning parent. We reject this approach because the start-up industry codes from VentureOne are not Standard Industrial Classification codes used in the public company Compustat database. Thus, one would have to map one set of codes into the other, an imprecise and coarse mapping. Instead, we measure the relatedness of the two firms based on the patents of the parent company and the patents associated with the industry of the start-up. This approach also has some shortcomings, not least of which is that many of the start-ups in our sample are not in industries that have significant numbers of firms with patents.

One challenge of this approach is defining what it means for patents to be related to each other. Above, it will be recalled, we employed the technology classification scheme developed by Hall, Jaffe, and Trajtenberg [2001], who divided the patent classes in the U.S. Patent Classification scheme into 36 distinct categories. Each of these 36 classes encompasses several U.S. patent classes. This classification scheme, while useful as a control, is probably too broad for the purpose of measuring relatedness.

To get around this difficulty, we base the analysis of relatedness on the International Patent Classification (IPC) scheme. The IPC system has its origins in the Council of Europe's 1954 "European Convention on the International Classification of Patents for Invention." The classification has been managed by an international (rather than 
a purely European) agency since 1969. Since that year, U.S. patents have been classified by patent examiners according to both the U.S. and IPC schemes (WIPO [1981]).

The IPC has at least two advantages over the U.S. classification (upon which the NBER categories are based). First, the IPC scheme is based on the usefulness of the patent for an industry or profession rather than being based on the structure and function of the patent. Thus, the IPC scheme reflects the economic importance of new inventions, as opposed to the technical focus of the U.S. scheme. Second, the first four levels of the IPC classifications are nested. This is in contrast with the U.S. system, where $435 / 40$ is a subset of $435 / 39$, which is in turn a subclass of $435 / 34$, but $435 / 41$ is not a subclass of any of these (USPTO [2003]). The non-nesting of the U.S. scheme would make it inadequate for our relatedness measure.

Because the IPC classification data is not included in the NBER Patent Citations Data File, we obtain this information from Thomson Delphion, a data vendor. For the public companies in our sample, we simply match the patents in our data to the Delphion database and extract the primary IPC classification. Getting the IPC classifications on the start-ups in our sample was more complex because they are generally not included in the NBER database. ${ }^{10}$ Thus, we identify their patents by searching for them on the USPTO website (www.uspto.gov). We restrict attention to start-ups in 21 industries with significant numbers of patents: e.g., we include wireless communications equipment and biotechnology but do not include business application software and physician-practice management. There are 1457 entrepreneurs leaving public companies to start firms in these industries, $28.2 \%$ of the entrepreneurs (for which we have industry data) who leave public companies. 
For each start-up in these industries, we record the patent numbers of the first five patents they received (although they usually they have fewer than five patents). Then for each of the VentureOne industries, we identify all 2-digit IPC patent classes that have at least five percent of the patents in that industry. For example, in wireless communication equipment there are four patent classes with at least $5 \%$ of the patents in the industry: measuring and testing (13.8\%), basic electric elements $(16.0 \%)$, basic electronic circuitry (7.5\%), and electric communication technique (55.3\%), collectively accounting for $92.6 \%$ of the patents in this industry. ${ }^{11}$ We then normalize these patent-class percentages by the cumulative percentage, e.g., dividing $13.8 \%$ by $92.6 \%(14.9 \%)$ to get the share of the measuring and testing patent class in all patent classes with a greater share than $5 \%$.

To measure the relatedness of the spawning company to the start-up, we calculate the share of the spawner's patents that are in the main patent classes of the start-up's industry. Because some of the patent classes in the start-up industry are more common than others - e.g., in wireless communication equipment, electric communication technique patents are more common than basic electronic circuitry-we weight the patent classes in this calculation by their industry share described in the preceding paragraph. For example, suppose the spawning company has 20 patents in all, 5 in electric communication technique (with a $59.7 \%$ share) and two in measuring and testing (with a $14.9 \%$ share), and the rest in other patent classes. Then our measure of relatedness would be $(59.7 \%$ x $5+14.9 \%$ x 2$) / 20$ $=16.4 \%$. The mean relatedness measure in our sample is $27.0 \%$ and the median is $22.6 \%$.

${ }^{10}$ The assignment of CUSIPs in the NBER Patent Citations Data File was done as of 1989. Firms that went public after 1989 do not have an assigned CUSIP in the file.

${ }^{11}$ In the 21 industries, the cumulative percentage of patents with at least a $5 \%$ industry share is typically between $80 \%$ and $100 \%$. 
We are now ready to examine the factors that affect the relatedness of the start-up to the spawning parent. As discussed above, it may be that the high spawners tend to spawn more simply because they have technologies that are more appropriate for venture capital. In this case, we would expect to see more related spawning from companies in Silicon Valley and Massachusetts and those that were also once venture capital backed. The regressions in Table IX examine this possibility and others.

The dependent variable in the regression is the relatedness measure discussed above, while the independent variables are similar to those in the earlier regressions. (We omit for obvious reasons the patent-based measures.) We present two sets of regressions, both with and without industry fixed effects. The industry dummies will control for cross-industry differences in our relatedness measure. ${ }^{12}$

The results indicate that companies located in Silicon Valley and Massachusetts tend to spawn less related ventures than companies outside these areas. This pattern is inconsistent with the view that the spawning patterns follow mechanically from the greater propensity of firms based in entrepreneurial regions to spawn more because they have technologies that are more relevant for venture capital investment. We similarly find a negative relationship between relatedness and prior venture capital backing of the spawning company; the coefficient is statistically significant in the first regression but insignificant in the other. This is also inconsistent with the view that the higher spawning level of venture capital backed firms is driven by differences in technology. The view is also inconsistent

\footnotetext{
${ }^{12}$ Some industries have more patent classes represented than others. As a result, in these industries the relatedness measure will tend to be lower than in industries with fewer patent classes represented. Industry dummies for the spawned start-up control for the cross-correlation that might follow if the industries with relatively more patent classes also tend to be the ones that are, say, located in Silicon Valley.
} 
with the Xerox-type spawning as that would imply that firms located outside the entrepreneurial regions would tend to spawn more outside their core business. Instead, they seem more likely to spawn related ventures.

The other findings are probably more mechanical in nature. Not surprisingly, larger firms and less focused firms tend to do more unrelated spawning (although the latter result appears only in the second regression). High Q firms and those with high lagged sales growth are also more likely to spawn related ventures. This is probably because the supply of good ideas in the core business is greater than in firms with low Q and low sales growth.

What do these results tell us about the spawning process? At this point, it is difficult to draw definitive conclusions, but we can offer two hypotheses that are consistent with the data. One hypothesis is that firms located in Silicon Valley and Massachusetts are more committed to remaining focused on their core lines of business and exploiting opportunities in their core. This pattern may stem from the fact that remaining focused is a key business value that venture capitalists try to instill in entrepreneurs and one that may have been critical in their success. ${ }^{13}$ Thus, these high spawning entrepreneurial firms in the main regions of venture capital activity may be more prone than other firms to reject new business opportunities outside their core lines. A second hypothesis is that these firms are better than others in identifying business opportunities in their core areas of specialization. In this case, venture capitalists would be less willing to fund new ventures from these companies because of adverse selection concerns. Thus, the new ventures that emerge from these firms are more likely to be outside the core business. At this point, these hypotheses remain purely speculative. We

\footnotetext{
${ }^{13}$ For evidence that supports this claim, see the discussions in Gupta [2000].
} 
can, however, conclude that the data are inconsistent with the view that the results are driven by systematic differences in the technologies of the high and low spawners.

\section{Conclusions and Suggestions for Future Research}

This paper examines the determinants of entrepreneurial spawning, i.e., the propensity of publicly traded corporations to spawn new venture capital backed firms. While entrepreneurial activity has received a tremendous amount of attention from academic researchers and the popular press, the source of new entrepreneurial firms has received relatively little systematic attention. We show that existing public companies are an important source of entrepreneurs for venture capital backed start-ups, particularly public corporations with patents in areas of interest to venture capital. Younger firms, that were backed by venture capitalists themselves and that are located in the main hubs of venture capital activity (Silicon Valley and Massachusetts) are more likely to spawn new firms. Moreover, firms focused in one main line of business are more likely to be the source of entrepreneurial ventures. Firms outside of Silicon Valley and Massachusetts not originally backed by venture capitalists are more likely to spawn businesses related to their core areas of specialization.

These findings appear to be inconsistent with the view that entrepreneurs start new firms in response to their frustration with large, bureaucratic companies. Instead, they suggest that the breeding grounds for entrepreneurial firms are other entrepreneurial firms. It is in these environments that employees learn from their co-workers about what it takes to start a new firm and are exposed to a network of suppliers and customers who are used to dealing with start-up companies. These spawning entrepreneurial firms may 
also implicitly select for less risk averse individuals who are willing to bear the greater risks of starting a new firm.

Our findings have several implications. In particular, they suggest that entrepreneurial activity in a given region has increasing returns (Saxenian [1994]). Stimulating entrepreneurship in a region with few existing entrepreneurial firms is difficult; there may be many individuals with the technological know-how to start a new venture capital backed firm, but many fewer who know how to start new companies. In addition, the network of suppliers and customers may not be strong enough to support a new venture. ${ }^{14}$ Policies that have sought to foster entrepreneurial and venture capitalactivity by providing capital or investment incentives may not be enough. Instead, regions may need to attract firms with existing pools of workers who have the "training and conditioning" to become entrepreneurs.

At the same time, the results suggest that the ultimate success (in terms of scale) of individual venture capital backed firms may be bounded. The analysis shows that when growth slows, employees are likely to leave their firms to start new ones. Thus, there may be limits to how big a venture capital backed firm can get while maintaining their most entrepreneurial employees.

There are a number of related research questions we plan to pursue. We list three of them here. First, we hope to supplement this analysis with a survey of spawned entrepreneurs. What reasons do they give for leaving their firm and starting a new one? How do the responses vary depending on the type of company from which the

\footnotetext{
${ }^{14}$ Lerner [1999] discusses the powerful political pressures that can lead to the scattering of venture capital funding across regions, as well as presenting evidence consistent with this view from one government program to finance small high-technology businesses.
} 
entrepreneur was spawned? Second, how does spawning affect the parent? In particular, does it have a negative effect on growth and performance of the spawning firm as its most creative employees leave to start new ventures? Finally, how do the characteristics of the spawning firms affect the success of the new ventures? For example, are entrepreneurs from more successful spawning firms more or less likely to be successful themselves? And, how do the characteristics of the spawning firm's patents affect the likelihood of success of the new venture? 


\section{References}

Berger Allen N., Nathan H. Miller, Mitchell A. Petersen, Raghuram G. Rajan, and Jeremy C. Stein (2002). Does Function Follow Organizational Form? Evidence From the Lending Practices of Large and Small Banks. Working Paper no. 8752, National Bureau of Economic Research.

Berger, Philip G., and Eli Ofek (1995). Diversification's Effect on Firm Value. Journal of Financial Economics 37: 39-65.

Braun, Ernest, and Stuart Macdonald (1982). Revolution in Miniature: The History and Impact of Semiconductor Electronics Re-Explored in an Updated and Revised Second Edition New York: Cambridge University Press.

Burton, M. Diane, Jesper Sørensen, and Christine Beckman (2002). Coming from Good Stock: Career Histories and New Venture Formation. Research in the Sociology of Organizations Forthcoming

Chesbrough, Henry (2002). Graceful Exits and Foregone Opportunities: Xerox's Management of its Technology Spin-off Organizations. Business History Review 76: forthcoming.

Christensen, Clayton M. (1997). The Innovator's Dilemma: When New Technologies Cause Great Firms to Fail Boston: Harvard Business School Press.

Gompers, Paul A. (1997). An Examination of Convertible Securities in Venture Capital Investments. Unpublished Working Paper, Harvard University.

Gompers, Paul A., and Josh Lerner (1999). The Venture Capital Cycle Cambridge: MIT Press.

Gromb, Denis, and David S. Scharfstein (2002). Entrepreneurship in Equilibrium. Working Paper no. 9001, National Bureau of Economic Research.

Gupta, Udayan (2000). Done Deals: Venture Capitalists Tell Their Stories Boston: Harvard Business School Press.

Hall, Bronwyn H., Adam B. Jaffe, and Manuel Trajtenberg (2001). The NBER Patent Citations Data File: Lessons, Insights and Methodological Tools. Working Paper no. 8498, National Bureau of Economic Research.

Hellmann, Thomas (2002). When Do Employees Become Entrepreneurs? Working Paper no. 1770, Graduate School of Business, Stanford University. 
Hellmann, Thomas, and Manju Puri (2000). The Interaction between Product Market and Financing Strategy: The Role of Venture Capital. Review of Financial Studies 13: 959984.

Henderson, Rebecca (1993). Underinvestment and Incompetence as Responses to Radical Innovation: Evidence from the Photolithographic Alignment Equipment Industry. Rand Journal of Economics 24: 248-270.

Holmes, Thomas J., and James A. Schmitz, Jr. (1990). A Theory of Entrepreneurship and Its Application to the Study of Business Transfers. Journal of Political Economy 98: 265-294.

Hunt, Brian, and Josh Lerner (1995). Xerox Technology Ventures: March 1995. Harvard Business School Case 9-295-127 (and teaching note \# 5-298-152).

Jaffe, Adam B., and Manuel Trajtenberg (2002). Patents, Citations and Innovations: A Window on the Knowledge Economy Cambridge: MIT Press.

Jovanovic, Boyan (1979). Job Marching and the Theory of Turnover. Journal of Political Economy 87: 972-990.

Kaplan, Steven N., and Luigi Zingales (1997). Do Investment-Cash Flow Sensitivities Provide Useful Measures of Financing Constraints? Quarterly Journal of Economics 112: $169-215$.

Kaplan, Steven N., and Per Strömberg (2002). Financial Contracting Meets the Real World: An Empirical Analysis of Venture Capital Contracts. Review of Economic Studies Forthcoming.

Kortum, Samuel, and Josh Lerner (2000). Assessing the Impact of Venture Capital on Innovation. Rand Journal of Economics 31: 674-692.

Lerner, Josh (1999). The Government as Venture Capitalist: The Long-Run Effects of the SBIR Program. Journal of Business 72: 285-318.

Mitchell, Mark L., and Kenneth Lehn (1990). Do Bad Bidders Become Good Targets? Journal of Political Economy 98: 372-398.

Saxenian, AnnaLee (1994). Regional Advantage: Culture and Competition in Silicon Valley and Route 128 Cambridge: Harvard University Press.

Scharfstein, David S. (1998). The Dark Side of Internal Capital Markets II: Evidence from Diversified Conglomerates. Working Paper no. 6352, National Bureau of Economic Research. 
Scharfstein, David S., and Jeremy C. Stein (2000). The Dark Side of Internal Capital Markets: Divisional Rent-Seeking and Inefficient Investment. Journal of Finance 55: 2537-2564.

Schoar, Antoinette (2002). Effects of Corporate Diversification on Productivity. Journal of Finance 57: 2379-2403.

Stein, Jeremy C. (2002). Information Production and Capital Allocation: Decentralized versus Hierarchical Firms. Journal of Finance 57: 1891-1921.

U.S. Department of Commerce, Patent and Trademark Office [USPTO] (2003). Manual of Classification Washington: USPTO.

World Intellectual Property Organization [WIPO] (1981). General Information on the Third Edition of the International Patent Classification Geneva: WIPO. 
Table I

Summary of Entrepreneurs

The sample is based on Venture One's database of 15,297 founders of 5,112 venture capital backed startups who received venture capital financings from 1986 to 1999. The previous employment history of the founders is tabulated. Public companies are those identified from Compustat. The fourth column lists the number of founders who are the CEO, President, or Chief Technology Officer of the start-up. The fifth column lists the number of founders whose most recent employer was a public company.

\begin{tabular}{|c|c|c|c|c|c|c|c|}
\hline Year & $\begin{array}{c}\text { Number of } \\
\text { Entrepreneurs }\end{array}$ & $\begin{array}{l}\text { Number of } \\
\text { Start-ups }\end{array}$ & $\begin{array}{c}\text { Number of } \\
\text { Technology } \\
\text { Start-ups }\end{array}$ & $\begin{array}{c}\text { CEO/Pres/ } \\
\text { CTO }\end{array}$ & $\begin{array}{l}\text { Number of } \\
\text { Entrepreneurs } \\
\text { from Public } \\
\text { Companies }\end{array}$ & $\begin{array}{l}\text { Fraction } \\
\text { from Public } \\
\text { Cos. }\end{array}$ & $\begin{array}{c}\text { Fraction from Public } \\
\text { Cos. When We Have } \\
\text { Previous Company } \\
\text { Identified }\end{array}$ \\
\hline 1986 & 483 & 221 & 144 & 268 & 145 & $30.0 \%$ & $45.9 \%$ \\
\hline 1987 & 628 & 260 & 171 & 325 & 196 & $31.2 \%$ & $43.6 \%$ \\
\hline 1988 & 694 & 267 & 172 & 359 & 229 & $33.0 \%$ & $44.2 \%$ \\
\hline 1989 & 721 & 292 & 176 & 392 & 246 & $34.1 \%$ & $43.6 \%$ \\
\hline 1990 & 843 & 333 & 214 & 463 & 295 & $35.0 \%$ & $44.3 \%$ \\
\hline 1991 & 840 & 345 & 222 & 484 & 307 & $36.5 \%$ & $45.1 \%$ \\
\hline 1992 & 1065 & 408 & 237 & 567 & 342 & $32.1 \%$ & $41.4 \%$ \\
\hline 1993 & 1016 & 384 & 221 & 606 & 380 & $37.4 \%$ & $46.3 \%$ \\
\hline 1994 & 1172 & 446 & 253 & 747 & 368 & $31.4 \%$ & $41.3 \%$ \\
\hline 1995 & 1290 & 527 & 257 & 906 & 417 & $32.3 \%$ & $41.4 \%$ \\
\hline 1996 & 1623 & 680 & 372 & 1236 & 599 & $36.9 \%$ & $44.6 \%$ \\
\hline 1997 & 1448 & 669 & 361 & 1109 & 535 & $36.9 \%$ & $42.6 \%$ \\
\hline 1998 & 1747 & 809 & 365 & 1376 & 692 & $39.6 \%$ & $45.0 \%$ \\
\hline 1999 & 1717 & 804 & 232 & 1396 & 717 & $41.8 \%$ & $46.5 \%$ \\
\hline
\end{tabular}




\section{Table II}

\section{Summary of Information on Previous Employer of Founders}

The sample is derived from public companies listed in Compustat during the period 1986-1999. A spawned entrepreneur is an employee who leaves a public company to start a venture capital backed firm. Data on founders come from the VentureOne database of 15,297 founders of 5,112 venture capital backed start-ups during the period 1986-1999. Panel A lists all public companies that spawn at least ten entrepreneurial teams during the sample period, 1986-1999, and the number of entrepreneurial teams they spawn during the sample period. (Multiple individuals departing to a single firm are regarded as a single entrepreneurial team.) Panel B lists all industries in which public companies spawn at least 20 entrepreneurs in total and the number of entrepreneurs they spawn.

Panel A: Top Public Spawning Companies

\begin{tabular}{|c|c|c|c|}
\hline Company & $\begin{array}{l}\text { Number of Spawned } \\
\text { Entrepreneurial Teams }\end{array}$ & Company & $\begin{array}{l}\text { Number of Spawned } \\
\text { Entrepreneurial Teams }\end{array}$ \\
\hline IBM & 70 & Nortel Networks & 17 \\
\hline AT\&T & 60 & Unisys & 17 \\
\hline Sun Microsystems & 55 & National Semiconductor & 17 \\
\hline Apple Computer & 48 & Advanced Micro Devices & 16 \\
\hline Hewlett-Packard & 46 & Mentor Graphics & 15 \\
\hline Oracle & 41 & Cirrus Logic & 14 \\
\hline General Electric & 37 & Genentech & 14 \\
\hline Microsoft & 30 & Bristol Myers Squibb & 14 \\
\hline Xerox & 29 & Raychem & 14 \\
\hline Baxter & 29 & Dun \& Bradstreet & 14 \\
\hline Intel & 28 & SmithKline Beecham & 13 \\
\hline Disney & 28 & $\mathrm{MCI}$ & 13 \\
\hline Silicon Graphics & 27 & Pfizer & 13 \\
\hline Lotus Development Corp. & 26 & Texas Instruments & 13 \\
\hline Motorola & 25 & Legent & 12 \\
\hline $\mathrm{DEC}$ & 24 & Tandem Computer & 12 \\
\hline Cadence Design Systems & 21 & Bank of America & 11 \\
\hline Johnson \& Johnson & 21 & Peoplesoft & 11 \\
\hline Verizon & 19 & Morgan Stanley & 11 \\
\hline Novell & 18 & Adaptec & 11 \\
\hline
\end{tabular}




\section{Table II (Continued)}

Panel B: Top Three Digit Industries for Spawners

\begin{tabular}{lc}
\hline Industry & $\begin{array}{c}\text { Number of Spawned } \\
\text { Entrepreneurial Teams }\end{array}$ \\
\hline Computer Programming and Data Processing & 1009 \\
Computer and Office Equipment & 588 \\
Drugs & 348 \\
Communication Equipment & 212 \\
Surgical, Medical, and Dental Instruments & 204 \\
Electronic Components and Accessories & 185 \\
Telephone Communications & 178 \\
Laboratory, Analytical, and Optical Equipment & 83 \\
Security Brokers, Dealers, And Flotation & 61 \\
Radio And Television Broadcasting Stations & 52 \\
Commercial Banks & 50 \\
Non-Store Retailers & 30 \\
Special Industry Machinery, Except Metalworking & 24 \\
\hline
\end{tabular}


Table III

\section{Characteristics of Public Spawners vs. Non-spawners}

The sample is derived from public companies listed in Compustat during the period 1986-1999. Spawners are identified as those public companies in which at least one employee left to start a venture capital backed firm. Data on founders come from the VentureOne database of 15,297 founders of 5,112 venture capital backed start-ups during the period 1986-1999. The table compares the characteristics of public companies that spawn at least one entrepreneur during the sample period 1986-1999 (the first three columns) to the characteristics of public companies that never spawn during the sample period (the second three columns). All dollar figures are in millions of 1999 dollars. Patent category 2 refers to computer and communication patents as classified in the NBER Patent Citations Data File and category 3 refers to medical and drug patents. The differences in the means are all statistically significant based on heteroskedasticity-consistent $\mathrm{t}$-statistics that adjust for non-independence of observations of the same firm over time.

\begin{tabular}{|c|c|c|c|c|c|c|}
\hline & \multicolumn{3}{|c|}{ Spawners } & \multicolumn{3}{|c|}{ Non-spawners } \\
\hline & Median & Mean & Observations & Median & Mean & Observations \\
\hline Sales (\$MMs) & $\$ 185.2$ & $\$ 3,428.6$ & 515 & $\$ 116.1$ & $\$ 1,343.3$ & 855 \\
\hline Assets (\$MMs) & $\$ 191.7$ & $\$ 4,949.1$ & 515 & $\$ 100.5$ & $\$ 1,732.6$ & 855 \\
\hline Employees (000s) & 23.1 & 44.2 & 515 & 0.8 & 8.0 & 855 \\
\hline Winsorized Sales Growth* & $19.3 \%$ & $52.6 \%$ & 515 & $11.2 \%$ & $37.6 \%$ & 855 \\
\hline Winsorized Tobin's Q* & 2.18 & 2.75 & 515 & 1.71 & 2.54 & 855 \\
\hline EBITDA/Assets & 0.111 & 0.058 & 515 & 0.107 & 0.054 & 855 \\
\hline Venture Capital-Backed & & $35.5 \%$ & 515 & & $12.2 \%$ & 855 \\
\hline Silicon Valley & & $19.8 \%$ & 515 & & $5.9 \%$ & 855 \\
\hline Massachusetts & & $9.9 \%$ & 515 & & $5.9 \%$ & 855 \\
\hline Number of Spawned & & & & & & \\
\hline Entrepreneurs & 2 & 4.07 & 515 & & & \\
\hline Any patents & & $28.4 \%$ & 515 & & $28.4 \%$ & 855 \\
\hline $\begin{array}{l}\text { Number of Patents in } \\
\text { Category } 2\end{array}$ & 4 & 137.5 & 515 & 2 & 15.9 & 855 \\
\hline Number of Patents in & & & & & & \\
\hline Category 3 & 0 & 51.2 & 515 & 0 & 10.8 & 855 \\
\hline Patent Quality & 0.618 & 1.336 & 515 & -0.922 & -0.606 & 855 \\
\hline Patent Originality & 0.019 & 0.019 & 515 & 0.062 & 0.059 & 855 \\
\hline
\end{tabular}

${ }^{*}$ Observations with greater than the $99^{\text {th }}$ percentile are coded as being at this level. 
Table IV

Regression Analyses of Spawning Levels

The table presents regression results for the cumulative number of spawned entrepreneurs for each firm in our sample. The sample is derived from public companies listed in Compustat during the period 1986-1999 with patents in either Computer and Communications or Drugs and Medical based on the NBER Patent Citations Data File classification scheme. The dependent variable in the regressions is the natural logarithm of the cumulative number of venture capital backed entrepreneurs spawned over the whole sample period. The information on entrepreneurs comes from a sample of 15,297 founders of 5,112 venture capital backed start-ups in the VentureOne database of venture capital financing who received venture capital financing between 1986 and 1999. Independent variables include the natural logarithm of inflation-adjusted firm size, the firm's sales growth over the previous three years winsorized at the $99^{\text {th }}$ percentile, Tobin's Q for the firm winsorized at the $99^{\text {th }}$ percentile, the natural logarithm of patents in six patent categories, dummy variables indicating whether the firm was backed by venture capitalists, dummy variables indicating if the firm was located in Silicon Valley or Massachusetts, measures for the firm's patent originality, the natural logarithm of firm age, and a dummy variable that equals one if the firm reports only one industry segment in Compustat. All regressions include year dummies for every year that the firm is in the sample, though the coefficients are not shown; some include industry fixed effects. Heteroskedasticity-consistent tstatistics in parentheses adjust for non-independence of observations of the same firm over time.

\begin{tabular}{|c|c|c|c|c|}
\hline & \multicolumn{4}{|c|}{ Dependent Variable: Log of Number of Entrepreneurs Spawned } \\
\hline & Total Spawning & $\begin{array}{c}\text { Technology } \\
\text { Spawning }\end{array}$ & Total Spawning & $\begin{array}{c}\text { Technology } \\
\text { Spawning }\end{array}$ \\
\hline Independent Variables & (1) & $(2)$ & (3) & (4) \\
\hline Log of Chemical Patents & $\begin{array}{c}-0.0191 \\
{[-1.18]}\end{array}$ & $\begin{array}{c}-0.0146 \\
{[-1.08]}\end{array}$ & $\begin{array}{c}-0.0093 \\
{[-0.51]}\end{array}$ & $\begin{array}{c}-0.0067 \\
{[-0.39]}\end{array}$ \\
\hline $\begin{array}{l}\text { Log of Computer and Communications } \\
\text { Patents }\end{array}$ & $\begin{array}{l}0.2203 \\
{[6.75]}\end{array}$ & $\begin{array}{c}0.1958 \\
{[6.34]}\end{array}$ & $\begin{array}{l}0.1864 \\
{[8.60]}\end{array}$ & $\begin{array}{l}0.1707 \\
{[8.35]}\end{array}$ \\
\hline Log of Drugs and Medical Patents & $\begin{array}{l}0.1443 \\
{[8.99]}\end{array}$ & $\begin{array}{l}0.1449 \\
{[9.99]}\end{array}$ & $\begin{array}{l}0.1384 \\
{[6.74]}\end{array}$ & $\begin{array}{l}0.1431 \\
{[7.27]}\end{array}$ \\
\hline Log of Electrical and Electronic Patents & $\begin{array}{l}-0.0259 \\
{[-0.82]}\end{array}$ & $\begin{array}{l}0.0012 \\
{[0.05]}\end{array}$ & $\begin{array}{l}0.0008 \\
{[0.04]}\end{array}$ & $\begin{array}{l}0.0221 \\
{[1.17]}\end{array}$ \\
\hline Log of Mechanical Patents & $\begin{array}{c}-0.0376 \\
{[-2.45]}\end{array}$ & $\begin{array}{l}-0.0457 \\
{[-2.81]}\end{array}$ & $\begin{array}{l}-0.0673 \\
{[-3.12]}\end{array}$ & $\begin{array}{l}-0.0752 \\
{[-3.66]}\end{array}$ \\
\hline Log of Other Patents & $\begin{array}{c}-0.0614 \\
{[-4.19]}\end{array}$ & $\begin{array}{l}-0.0616 \\
{[-5.23]}\end{array}$ & $\begin{array}{l}-0.0556 \\
{[-2.50]}\end{array}$ & $\begin{array}{l}-0.0579 \\
{[-2.81]}\end{array}$ \\
\hline Log of Real Assets & $\begin{array}{l}0.1250 \\
{[7.77]}\end{array}$ & $\begin{array}{l}0.0897 \\
{[7.40]}\end{array}$ & $\begin{array}{l}0.1504 \\
{[9.11]}\end{array}$ & $\begin{array}{l}0.1143 \\
{[7.26]}\end{array}$ \\
\hline Mean EBITDA/Assets & $\begin{array}{c}-0.1380 \\
{[-1.42]}\end{array}$ & $\begin{array}{r}-0.0891 \\
{[-1.23]}\end{array}$ & $\begin{array}{l}-0.3679 \\
{[-2.89]}\end{array}$ & $\begin{array}{c}-0.2788 \\
{[-2.27]}\end{array}$ \\
\hline $\begin{array}{l}\text { Mean Winsorized Sales Growth Over } \\
\text { Previous Year }\end{array}$ & $\begin{array}{l}0.0122 \\
{[0.88]}\end{array}$ & $\begin{array}{l}0.0062 \\
{[0.42]}\end{array}$ & $\begin{array}{l}0.0131 \\
{[0.73]}\end{array}$ & $\begin{array}{l}0.0082 \\
{[0.42]}\end{array}$ \\
\hline Mean Winsorized Tobin's Q* & $\begin{array}{l}0.0219 \\
{[3.70]}\end{array}$ & $\begin{array}{l}0.0157 \\
{[3.70]}\end{array}$ & $\begin{array}{l}0.0149 \\
{[1.45]}\end{array}$ & $\begin{array}{l}0.0115 \\
{[1.18]}\end{array}$ \\
\hline Venture Capital-Backed & $\begin{array}{l}0.2335 \\
{[6.11]}\end{array}$ & $\begin{array}{l}0.2135 \\
{[9.61]}\end{array}$ & $\begin{array}{l}0.1895 \\
{[3.89]}\end{array}$ & $\begin{array}{l}0.1728 \\
{[3.56]}\end{array}$ \\
\hline Silicon Valley-Based & $\begin{array}{c}0.3772 \\
{[6.93]}\end{array}$ & $\begin{array}{l}0.3875 \\
{[7.08]}\end{array}$ & $\begin{array}{c}0.3461 \\
{[5.17]}\end{array}$ & $\begin{array}{l}0.3606 \\
{[5.43]}\end{array}$ \\
\hline Massachusetts-Based & $\begin{array}{l}0.2355 \\
{[3.62]}\end{array}$ & $\begin{array}{c}0.2066 \\
{[2.96]}\end{array}$ & $\begin{array}{c}0.2013 \\
{[3.26]}\end{array}$ & $\begin{array}{l}0.1793 \\
{[2.91]}\end{array}$ \\
\hline Focused Firm & $\begin{array}{c}0.1952 \\
{[2.69]}\end{array}$ & $\begin{array}{c}0.1484 \\
{[2.64]}\end{array}$ & $\begin{array}{l}0.1893 \\
{[3.42]}\end{array}$ & $\begin{array}{c}0.1438 \\
{[2.76]}\end{array}$ \\
\hline Log of Firm Age & $\begin{array}{c}-0.0575 \\
{[-2.36]}\end{array}$ & $\begin{array}{c}-0.0603 \\
{[-2.60]}\end{array}$ & $\begin{array}{c}-0.0488 \\
{[-1.96]}\end{array}$ & $\begin{array}{c}-0.0552 \\
{[-2.38]}\end{array}$ \\
\hline Patent Quality & $\begin{array}{c}0.0061 \\
{[4.74]}\end{array}$ & $\begin{array}{c}0.0066 \\
{[4.23]}\end{array}$ & $\begin{array}{c}0.0043 \\
{[1.73]}\end{array}$ & $\begin{array}{l}0.0049 \\
{[2.08]}\end{array}$ \\
\hline Patent Originality & $\begin{array}{c}-0.0841 \\
{[-1.05]}\end{array}$ & $\begin{array}{c}0.0257 \\
{[0.49]}\end{array}$ & $\begin{array}{c}-0.1473 \\
{[-1.81]}\end{array}$ & $\begin{array}{c}-0.0279 \\
{[-0.37]}\end{array}$ \\
\hline Constant & $\begin{array}{c}-0.8499 \\
{[-6.21]}\end{array}$ & $\begin{array}{c}-0.7153 \\
{[-6.25]}\end{array}$ & $\begin{array}{c}-0.9714 \\
{[-9.48]}\end{array}$ & $\begin{array}{c}-0.8285 \\
{[-8.35]}\end{array}$ \\
\hline Number of Observations & 1,370 & 1,370 & 1,370 & 1,370 \\
\hline Adjusted R-squared & 0.418 & 0.403 & 0.433 & 0.400 \\
\hline Industry Fixed Effects & No & No & Yes & Yes \\
\hline
\end{tabular}

${ }^{*}$ Observations with greater than the $99^{\text {th }}$ percentile are coded as equal to the $99^{\text {th }}$ percentile. 
Table V

Regression Analyses of Likelihood of Doing Any Spawning

The table presents regressions of the probability of a sample firm having any spawning activity. The sample is derived from public companies listed in Compustat during the period 1986-1999 with patents in either Computer and Communications or Drugs and Medical based on the NBER Patent Citations Data File classification scheme. The dependent variable in the regressions is a dummy variable that equals one if the firm ever spawns at least one venture capital backed entrepreneurs. The information on entrepreneurs comes from a sample of 15,297 founders of 5,112 venture capital backed start-ups in the VentureOne database of venture capital financing who received venture capital financing between 1986 and 1999. Independent variables include the natural logarithm of inflation-adjusted firm size, the firm's sales growth over the previous three years winsorized at the $99^{\text {th }}$ percentile, Tobin's Q for the firm winsorized at the $99^{\text {th }}$ percentile, the natural logarithm of patents in six patent categories, dummy variables indicating whether the firm was backed by venture capitalists, dummy variables indicating if the firm was located in Silicon Valley or Massachusetts, measures for the firm's patent originality, the natural logarithm of firm age, and a dummy variable that equals one if the firm reports only one industry segment in Compustat. All regressions include year dummies for each year that the firm is in our sample, though the coefficients are not shown; some include industry fixed effects. Heteroskedasticity-consistent t-statistics in parentheses adjust for non-independence of observations of the same firm over time.

\begin{tabular}{|c|c|c|c|c|}
\hline & \multicolumn{4}{|c|}{ Dependent Variable: Dummy Variable Indicating Any Spawning } \\
\hline & Total Spawning & $\begin{array}{c}\text { Technology } \\
\text { Spawning } \\
\end{array}$ & Total Spawning & $\begin{array}{c}\text { Technology } \\
\text { Spawning }\end{array}$ \\
\hline Independent Variables & $(1)$ & $(2)$ & $(3)$ & $(4)$ \\
\hline Log of Chemical Patents & $\begin{array}{r}-0.0035 \\
{[-0.35]}\end{array}$ & $\begin{array}{r}-0.0062 \\
{[-0.99]}\end{array}$ & $\begin{array}{l}0.0059 \\
{[0.44]}\end{array}$ & $\begin{array}{l}0.0009 \\
{[0.08]}\end{array}$ \\
\hline $\begin{array}{l}\text { Log of Computer and Communications } \\
\text { Patents }\end{array}$ & $\begin{array}{l}0.0921 \\
{[7.14]}\end{array}$ & $\begin{array}{l}0.0902 \\
{[7.26]}\end{array}$ & $\begin{array}{l}0.0746 \\
{[5.71]}\end{array}$ & $\begin{array}{l}0.0729 \\
{[6.11]}\end{array}$ \\
\hline Log of Drugs and Medical Patents & $\begin{array}{l}0.0755 \\
{[7.66]}\end{array}$ & $\begin{array}{l}0.0842 \\
{[11.71]}\end{array}$ & $\begin{array}{l}0.0669 \\
{[5.32]}\end{array}$ & $\begin{array}{l}0.0811 \\
{[6.97]}\end{array}$ \\
\hline Log of Electrical and Electronic Patents & $\begin{array}{r}-0.0015 \\
{[-0.09]}\end{array}$ & $\begin{array}{l}0.0107 \\
{[0.79]}\end{array}$ & $\begin{array}{l}0.0105 \\
{[0.73]}\end{array}$ & $\begin{array}{l}0.0211 \\
{[1.56]}\end{array}$ \\
\hline Log of Mechanical Patents & $\begin{array}{l}-0.0276 \\
{[-1.95]}\end{array}$ & $\begin{array}{r}-0.0367 \\
{[-3.31]}\end{array}$ & $\begin{array}{c}-0.0496 \\
{[-3.03]}\end{array}$ & $\begin{array}{c}-0.0592 \\
{[-4.11]}\end{array}$ \\
\hline Log of Other Patents & $\begin{array}{c}-0.0446 \\
{[-2.85]}\end{array}$ & $\begin{array}{l}-0.0478 \\
{[-4.50]}\end{array}$ & $\begin{array}{l}-0.0438 \\
{[-2.75]}\end{array}$ & $\begin{array}{r}-0.0449 \\
{[-3.11]}\end{array}$ \\
\hline Log of Real Assets & $\begin{array}{l}0.0654 \\
{[8.40]}\end{array}$ & $\begin{array}{l}0.0544 \\
{[7.32]}\end{array}$ & $\begin{array}{l}0.0830 \\
{[8.72]}\end{array}$ & $\begin{array}{l}0.0707 \\
{[7.82]}\end{array}$ \\
\hline Mean EBITDA/Assets & $\begin{array}{r}-0.1451 \\
{[-2.56]}\end{array}$ & $\begin{array}{r}-0.1290 \\
{[-2.25]}\end{array}$ & $\begin{array}{r}-0.2911 \\
{[-2.99]}\end{array}$ & $\begin{array}{r}-0.2570 \\
{[-2.78]}\end{array}$ \\
\hline $\begin{array}{l}\text { Mean Winsorized Sales Growth Over } \\
\text { Previous Year }\end{array}$ & $\begin{array}{l}0.0263 \\
{[1.59]}\end{array}$ & $\begin{array}{l}0.0094 \\
{[0.58]}\end{array}$ & $\begin{array}{l}0.0259 \\
{[1.61]}\end{array}$ & $\begin{array}{l}0.0098 \\
{[0.61]}\end{array}$ \\
\hline Mean Winsorized Tobin's Q ${ }^{*}$ & $\begin{array}{l}0.0024 \\
{[0.49]}\end{array}$ & $\begin{array}{l}0.0010 \\
{[0.34]}\end{array}$ & $\begin{array}{c}-0.0002 \\
{[-0.03]}\end{array}$ & $\begin{array}{c}-0.0002 \\
{[-0.03]}\end{array}$ \\
\hline Venture Capital-Backed & $\begin{array}{c}0.2024 \\
{[8.56]}\end{array}$ & $\begin{array}{c}0.1865 \\
{[9.54]}\end{array}$ & $\begin{array}{c}0.1780 \\
{[4.89]}\end{array}$ & $\begin{array}{c}0.1688 \\
{[4.71]}\end{array}$ \\
\hline Silicon Valley-Based & $\begin{array}{c}0.1644 \\
{[4.39]}\end{array}$ & $\begin{array}{c}0.1947 \\
{[4.93]}\end{array}$ & $\begin{array}{c}0.1431 \\
{[3.34]}\end{array}$ & $\begin{array}{c}0.1766 \\
{[4.10]}\end{array}$ \\
\hline Massachusetts-Based & $\begin{array}{c}0.1363 \\
{[3.43]}\end{array}$ & $\begin{array}{c}0.1405 \\
{[3.56]}\end{array}$ & $\begin{array}{c}0.1146 \\
{[2.53]}\end{array}$ & $\begin{array}{l}0.1247 \\
{[2.79]}\end{array}$ \\
\hline Focused Firm & $\begin{array}{c}0.0838 \\
{[2.22]}\end{array}$ & $\begin{array}{c}0.0592 \\
{[2.13]}\end{array}$ & $\begin{array}{c}0.0756 \\
{[1.92]}\end{array}$ & $\begin{array}{l}0.0571 \\
{[1.58]}\end{array}$ \\
\hline Log of Firm Age & $\begin{array}{c}-0.0271 \\
{[-1.23]}\end{array}$ & $\begin{array}{c}-0.0389 \\
{[-1.97]}\end{array}$ & $\begin{array}{c}-0.0205 \\
{[-1.19]}\end{array}$ & $\begin{array}{c}-0.0327 \\
{[-2.05]}\end{array}$ \\
\hline Patent Quality & $\begin{array}{c}0.0032 \\
{[3.30]}\end{array}$ & $\begin{array}{c}0.0039 \\
{[3.11]}\end{array}$ & $\begin{array}{c}0.0021 \\
{[1.10]}\end{array}$ & $\begin{array}{l}0.0029 \\
{[1.57]}\end{array}$ \\
\hline Patent Originality & $\begin{array}{c}-0.0816 \\
{[-1.19]}\end{array}$ & $\begin{array}{c}0.0047 \\
{[0.11]}\end{array}$ & $\begin{array}{c}-0.1202 \\
{[-1.75]}\end{array}$ & $\begin{array}{c}-0.0255 \\
{[-0.40]}\end{array}$ \\
\hline Constant & $\begin{array}{c}-0.2417 \\
{[-3.34]}\end{array}$ & $\begin{array}{c}-0.2460 \\
{[-4.95]}\end{array}$ & $\begin{array}{c}-0.3253 \\
{[-4.69]}\end{array}$ & $\begin{array}{c}-0.3321 \\
{[-5.00]}\end{array}$ \\
\hline Number of Observations & 1,370 & 1,370 & 1,370 & 1,370 \\
\hline Adjusted R-squared & 0.275 & 0.300 & 0.277 & 0.292 \\
\hline Industry Fixed Effects & No & No & Yes & Yes \\
\hline
\end{tabular}

* Observations with greater than the $99^{\text {th }}$ percentile are coded as equal to the $99^{\text {th }}$ percentile. 
Table VI

Regression Analyses of Cumulative Spawning Levels Conditional on Any Spawning

The table presents regressions of the cumulative spawning rates for firms, conditional on the firms doing any spawning during our sample period. The sample is derived from public companies listed in Compustat during the period 1986-1999 with patents in either Computer and Communications or Drugs and Medical based on the NBER Patent Citations Data File classification scheme. The dependent variable in the regressions is the natural logarithm of the cumulative number of venture capital backed entrepreneurs spawned over the entire sample period from these public companies. The information on entrepreneurs comes from a sample of 15,297 founders of 5,112 venture capital backed start-ups in the VentureOne database of venture capital financing who received venture capital financing between 1986 and 1999. Independent variables include the natural logarithm of inflation-adjusted firm size, the firm's sales growth over the previous three years winsorized at the $99^{\text {th }}$ percentile, Tobin's Q for the firm winsorized at the $99^{\text {th }}$ percentile, the natural logarithm of patents in six patent categories, dummy variables indicating whether the firm was backed by venture capitalists, dummy variables indicating if the firm was located in Silicon Valley or Massachusetts, measures for the firm's patent originality, the natural logarithm of firm age, and a dummy variable that equals one if the firm reports only one industry segment in Compustat. All regressions include year dummies for each year that the firm is in our sample, though the coefficients are not shown; some include industry fixed effects. Heteroskedasticity-consistent t-statistics in parentheses adjust for non-independence of observations of the same firm over time.

\begin{tabular}{|c|c|c|c|c|}
\hline & \multicolumn{4}{|c|}{ Dependent Variable: Conditional Spawning Level } \\
\hline & Total Spawning & $\begin{array}{l}\text { Technology } \\
\text { Spawning }\end{array}$ & Total Spawning & $\begin{array}{c}\text { Technology } \\
\text { Spawning }\end{array}$ \\
\hline Independent Variables & (1) & $(2)$ & (3) & (4) \\
\hline Log of Chemical Patents & $\begin{array}{c}-0.0135 \\
{[-0.77]}\end{array}$ & $\begin{array}{c}-0.0014 \\
{[-0.06]}\end{array}$ & $\begin{array}{c}-0.0016 \\
{[-0.05]}\end{array}$ & $\begin{array}{l}0.0182 \\
{[0.52]}\end{array}$ \\
\hline $\begin{array}{l}\text { Log of Computer and Communications } \\
\text { Patents }\end{array}$ & $\begin{array}{l}0.1963 \\
{[4.60]}\end{array}$ & $\begin{array}{l}0.2056 \\
{[4.62]}\end{array}$ & $\begin{array}{l}0.1333 \\
{[4.24]}\end{array}$ & $\begin{array}{l}0.1447 \\
{[3.89]}\end{array}$ \\
\hline Log of Drugs and Medical Patents & $\begin{array}{l}0.1047 \\
{[9.14]}\end{array}$ & $\begin{array}{l}0.1111 \\
{[8.10]}\end{array}$ & $\begin{array}{l}0.1064 \\
{[3.55]}\end{array}$ & $\begin{array}{l}0.1015 \\
{[2.96]}\end{array}$ \\
\hline Log of Electrical and Electronic Patents & $\begin{array}{c}-0.0439 \\
{[-1.03]}\end{array}$ & $\begin{array}{c}-0.0346 \\
{[-0.80]}\end{array}$ & $\begin{array}{c}-0.0169 \\
{[-0.60]}\end{array}$ & $\begin{array}{c}-0.0206 \\
{[-0.64]}\end{array}$ \\
\hline Log of Mechanical Patents & $\begin{array}{l}-0.0306 \\
{[-0.59]}\end{array}$ & $\begin{array}{c}-0.0326 \\
{[-0.77]}\end{array}$ & $\begin{array}{l}-0.0595 \\
{[-1.67]}\end{array}$ & $\begin{array}{l}-0.0535 \\
{[-1.20]}\end{array}$ \\
\hline Log of Other Patents & $\begin{array}{l}-0.0263 \\
{[-0.51]}\end{array}$ & $\begin{array}{c}-0.0236 \\
{[-0.40]}\end{array}$ & $\begin{array}{l}0.0120 \\
{[0.29]}\end{array}$ & $\begin{array}{l}0.0235 \\
{[0.46]}\end{array}$ \\
\hline Log of Real Assets & $\begin{array}{l}0.1433 \\
{[7.82]}\end{array}$ & $\begin{array}{l}0.0844 \\
{[3.18]}\end{array}$ & $\begin{array}{l}0.1870 \\
{[6.36]}\end{array}$ & $\begin{array}{l}0.1321 \\
{[4.04]}\end{array}$ \\
\hline Mean EBITDA/Assets & $\begin{array}{r}-0.1071 \\
{[-0.76]}\end{array}$ & $\begin{array}{l}0.0090 \\
{[0.06]}\end{array}$ & $\begin{array}{l}-0.5791 \\
{[-2.86]}\end{array}$ & $\begin{array}{c}-0.4348 \\
{[-1.86]}\end{array}$ \\
\hline $\begin{array}{l}\text { Mean Winsorized Sales Growth Over } \\
\text { Previous Year }\end{array}$ & $\begin{array}{r}-0.0141 \\
{[-0.91]}\end{array}$ & $\begin{array}{l}0.0171 \\
{[0.74]}\end{array}$ & $\begin{array}{c}-0.0086 \\
{[-0.43]}\end{array}$ & $\begin{array}{l}0.0279 \\
{[1.00]}\end{array}$ \\
\hline Mean Winsorized Tobin's Q* & $\begin{array}{l}0.0390 \\
{[5.31]}\end{array}$ & $\begin{array}{l}0.0351 \\
{[4.14]}\end{array}$ & $\begin{array}{l}0.0418 \\
{[2.50]}\end{array}$ & $\begin{array}{l}0.0305 \\
{[1.70]}\end{array}$ \\
\hline Venture Capital-Backed & $\begin{array}{l}0.0261 \\
{[0.56]}\end{array}$ & $\begin{array}{l}0.0267 \\
{[0.54]}\end{array}$ & $\begin{array}{l}0.0229 \\
{[0.37]}\end{array}$ & $\begin{array}{l}0.0068 \\
{[0.10]}\end{array}$ \\
\hline Silicon Valley-Based & $\begin{array}{l}0.3091 \\
{[4.81]}\end{array}$ & $\begin{array}{c}0.2790 \\
{[3.81]}\end{array}$ & $\begin{array}{c}0.2774 \\
{[3.94]}\end{array}$ & $\begin{array}{c}0.2528 \\
{[3.52]}\end{array}$ \\
\hline Massachusetts-Based & $\begin{array}{l}0.1773 \\
{[1.58]}\end{array}$ & $\begin{array}{c}0.1356 \\
{[1.10]}\end{array}$ & $\begin{array}{l}0.1565 \\
{[1.88]}\end{array}$ & $\begin{array}{l}0.0972 \\
{[1.00]}\end{array}$ \\
\hline Focused Firm & $\begin{array}{c}0.1987 \\
{[1.98]}\end{array}$ & $\begin{array}{c}0.1124 \\
{[1.27]}\end{array}$ & $\begin{array}{c}0.1469 \\
{[1.58]}\end{array}$ & $\begin{array}{c}0.0844 \\
{[0.83]}\end{array}$ \\
\hline Log of Firm Age & $\begin{array}{c}-0.0933 \\
{[-1.31]}\end{array}$ & $\begin{array}{c}-0.0837 \\
{[-1.74]}\end{array}$ & $\begin{array}{c}-0.0980 \\
{[-1.78]}\end{array}$ & $\begin{array}{c}-0.1059 \\
{[-1.76]}\end{array}$ \\
\hline Patent Quality & $\begin{array}{c}0.0081 \\
{[2.11]}\end{array}$ & $\begin{array}{c}0.0103 \\
{[1.74]}\end{array}$ & $\begin{array}{c}0.0070 \\
{[1.73]}\end{array}$ & $\begin{array}{c}0.0089 \\
{[2.16]}\end{array}$ \\
\hline Patent Originality & $\begin{array}{c}-0.0352 \\
{[-0.30]}\end{array}$ & $\begin{array}{c}0.0462 \\
{[0.46]}\end{array}$ & $\begin{array}{c}-0.1135 \\
{[-0.79]}\end{array}$ & $\begin{array}{r}-0.0387 \\
{[-0.24]}\end{array}$ \\
\hline Constant & $\begin{array}{c}-0.2614 \\
{[-1.36]}\end{array}$ & $\begin{array}{c}-0.1001 \\
{[-0.51]}\end{array}$ & $\begin{array}{c}-0.5022 \\
{[-3.29]}\end{array}$ & $\begin{array}{c}-0.3132 \\
{[-1.84]}\end{array}$ \\
\hline Number of Observations & 515 & 428 & 515 & 428 \\
\hline Adjusted R-squared & 0.440 & 0.406 & 0.443 & 0.401 \\
\hline Industry Fixed Effects & No & No & Yes & Yes \\
\hline
\end{tabular}

* Observations with greater than the $99^{\text {th }}$ percentile are coded as equal to the $99^{\text {th }}$ percentile. 
Table VII

Cross Sectional Regression Analyses of Annual Spawning Levels

The regression are pooled cross-sectional regressions or the between estimators from fixed effects regressions of annual spawning levels for publicly traded firms. The sample is derived from public companies listed in Compustat during the period 1986-1999 with patents in either Computer and Communications or Drugs and Medical based on the NBER Patent Citations Data File classification scheme. The dependent variable in the regressions is the natural logarithm of the number of venture capital backed entrepreneurs spawned in a given year from these public companies. The information on entrepreneurs comes from a sample of 15,297 founders of 5,112 venture capital backed start-ups in the VentureOne database of venture capital financing who received venture capital financing between 1986 and 1999. Independent variables include the natural logarithm of inflation-adjusted firm size, the firm's sales growth over the previous three years winsorized at the $99^{\text {th }}$ percentile, Tobin's Q for the firm winsorized at the $99^{\text {th }}$ percentile, the natural logarithm of patents in six patent categories, dummy variables indicating whether the firm was backed by venture capitalists, dummy variables indicating if the firm was located in Silicon Valley or Massachusetts, measures for the firm's patent originality, the natural logarithm of firm age, and a dummy variable that equals one if the firm reports only one industry segment in Compustat. All regressions include year dummies, though the coefficients are not shown; some include industry fixed effects. All regressions include year dummies, though the coefficients are not shown; some include industry or firm fixed effects. Heteroskedasticity-consistent tstatistics in parentheses adjust for non-independence of observations of the same firm over time.

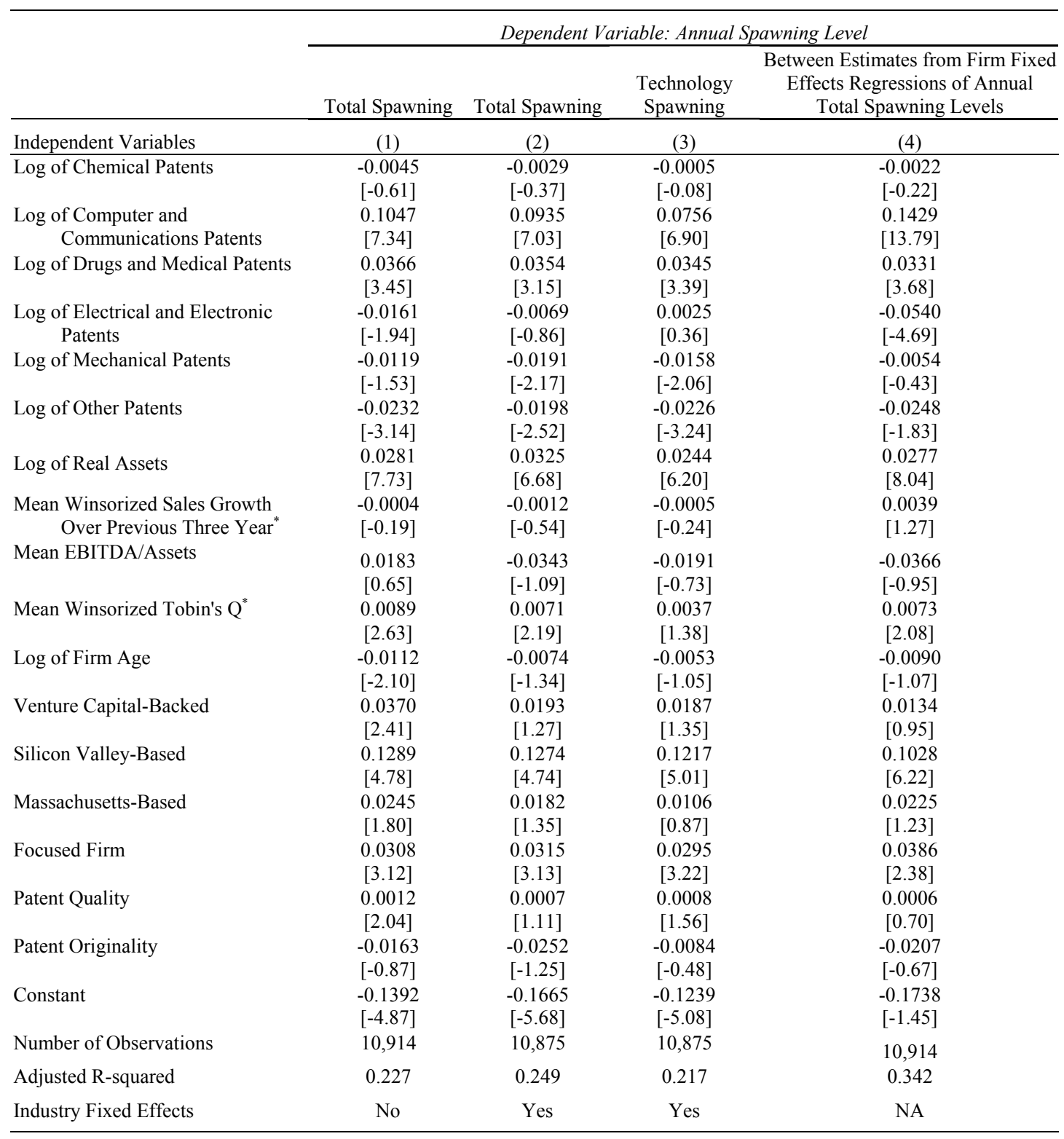

${ }^{*}$ Observations with greater than the $99^{\text {th }}$ percentile are coded as equal to the $99^{\text {th }}$ percentile. 
Table VIII

Firm Fixed-Effects Regression Analyses of Annual Spawning Levels

The table presents the firm fixed-effects regressions for the sample of publicly traded spawning firms. The sample is derived from public companies listed in Compustat during the period 1986-1999 with patents in either Computer and Communications or Drugs and Medical based on the NBER Patent Citations Data File classification scheme. The dependent variable in the regressions is the natural logarithm of the number of venture capital backed entrepreneurs spawned in a given year from these public companies. The information on entrepreneurs comes from a sample of 15,297 founders of 5,112 venture capital backed start-ups in the VentureOne database of venture capital financing who received venture capital financing between 1986 and 1999. Independent variables include the natural logarithm of inflation-adjusted firm size, the firm's sales growth over the previous three years winsorized at the $99^{\text {th }}$ percentile, the firm's industry sales growth over the previous three years winsorized at the $99^{\text {th }}$ percentile and deviations from that industry sales growth over the previous three years winsorized at the $99^{\text {th }}$ percentile, Tobin's $Q$ for the firm Winsorized at the $99^{\text {th }}$ percentile, the natural logarithm of patents in six patent categories, the natural logarithm of firm age, and a dummy variable that equals one if the firm reports only one industry segment in Compustat. All regressions include year dummies, though the coefficients are not shown; some include industry or firm fixed effects. Heteroskedasticity-consistent t-statistics in parentheses adjust for nonindependence of observations of the same firm over time.

\begin{tabular}{|c|c|c|c|c|}
\hline & \multicolumn{4}{|c|}{ Dependent Variable: Annual Spawning Level } \\
\hline & Total Spawning & $\begin{array}{c}\text { Technology } \\
\text { Spawning }\end{array}$ & Total Spawning & Total Spawning \\
\hline Independent Variables & (1) & $(2)$ & (3) & (4) \\
\hline Log of Chemical Patents & $\begin{array}{c}-0.0018 \\
{[-0.25]}\end{array}$ & $\begin{array}{l}0.0090 \\
{[1.43]}\end{array}$ & $\begin{array}{c}-0.0018 \\
{[-0.25]}\end{array}$ & $\begin{array}{c}-0.0020 \\
{[-0.28]}\end{array}$ \\
\hline $\begin{array}{l}\text { Log of Computer and Communications } \\
\text { Patents }\end{array}$ & $\begin{array}{l}0.0506 \\
{[6.94]}\end{array}$ & $\begin{array}{l}0.0319 \\
{[4.96]}\end{array}$ & $\begin{array}{l}0.0504 \\
{[6.94]}\end{array}$ & $\begin{array}{l}0.0501 \\
{[6.85]}\end{array}$ \\
\hline Log of Drugs and Medical Patents & $\begin{array}{l}0.0092 \\
{[1.35]}\end{array}$ & $\begin{array}{l}0.0062 \\
{[0.95]}\end{array}$ & $\begin{array}{l}0.0093 \\
{[1.36]}\end{array}$ & $\begin{array}{l}0.0092 \\
{[1.35]}\end{array}$ \\
\hline Log of Electrical and Electronic Patents & $\begin{array}{l}0.0002 \\
{[0.04]}\end{array}$ & $\begin{array}{l}0.0055 \\
{[0.97]}\end{array}$ & $\begin{array}{l}0.0002 \\
{[0.04]}\end{array}$ & $\begin{array}{l}-0.0001 \\
{[-0.02]}\end{array}$ \\
\hline Log of Mechanical Patents & $\begin{array}{l}-0.0076 \\
{[-1.20]}\end{array}$ & $\begin{array}{c}-0.0068 \\
{[-1.28]}\end{array}$ & $\begin{array}{c}-0.0074 \\
{[-1.18]}\end{array}$ & $\begin{array}{r}-0.0077 \\
{[-1.21]}\end{array}$ \\
\hline Log of Other Patents & $\begin{array}{r}-0.0001 \\
{[-0.01]}\end{array}$ & $\begin{array}{l}-0.0036 \\
{[-0.65]}\end{array}$ & $\begin{array}{l}0.0000 \\
{[0.00]}\end{array}$ & $\begin{array}{l}-0.0001 \\
{[-0.02]}\end{array}$ \\
\hline Log of Real Assets & $\begin{array}{l}0.0375 \\
{[6.29]}\end{array}$ & $\begin{array}{l}0.0291 \\
{[5.56]}\end{array}$ & $\begin{array}{l}0.0373 \\
{[6.27]}\end{array}$ & $\begin{array}{l}0.0392 \\
{[6.47]}\end{array}$ \\
\hline $\begin{array}{l}\text { Winsorized Sales Growth Over Previous } \\
\text { Three Year }\end{array}$ & $\begin{array}{l}-0.0059 \\
{[-3.04]}\end{array}$ & $\begin{array}{l}-0.0037 \\
{[-2.08]}\end{array}$ & & \\
\hline $\begin{array}{l}\text { Winsorized Deviation from Industry Sales } \\
\text { Growth Over Previous Three Year }\end{array}$ & & & $\begin{array}{c}-0.0060 \\
{[-3.08]}\end{array}$ & \\
\hline $\begin{array}{l}\text { Winsorized Industry Sales Growth Over } \\
\text { Previous Three Year }\end{array}$ & & & $\begin{array}{l}0.0048 \\
{[0.37]}\end{array}$ & \\
\hline $\begin{array}{l}\text { Sales Growth of Firm in the Highest } \\
\text { Quartile of Sales Growth }\end{array}$ & & & & $\begin{array}{l}-0.0121 \\
{[-2.09]}\end{array}$ \\
\hline $\begin{array}{c}\text { Sales Growth of Firm in the Lowest } \\
\text { Quartile of Sales Growth }\end{array}$ & & & & $\begin{array}{l}0.0101 \\
{[1.49]}\end{array}$ \\
\hline Mean EBITDA/Assets & $\begin{array}{c}-0.0173 \\
{[-0.74]}\end{array}$ & $\begin{array}{r}-0.0125 \\
{[-0.57]}\end{array}$ & $\begin{array}{r}-0.0185 \\
{[-0.78]}\end{array}$ & $\begin{array}{r}-0.0099 \\
{[-0.41]}\end{array}$ \\
\hline Mean Winsorized Tobin's Q ${ }^{*}$ & $\begin{array}{l}0.0006 \\
{[0.22]}\end{array}$ & $\begin{array}{r}-0.0015 \\
{[-0.64]}\end{array}$ & $\begin{array}{l}0.0005 \\
{[0.22]}\end{array}$ & $\begin{array}{l}0.0007 \\
{[0.00]}\end{array}$ \\
\hline Log of Firm Age & $\begin{array}{c}-0.0246 \\
{[-1.83]}\end{array}$ & $\begin{array}{c}-0.0004 \\
{[-0.03]}\end{array}$ & $\begin{array}{l}-0.0245 \\
{[-1.82]}\end{array}$ & $\begin{array}{l}-0.0247 \\
{[-1.82]}\end{array}$ \\
\hline Focused Firm & $\begin{array}{l}0.0023 \\
{[0.27]}\end{array}$ & $\begin{array}{l}0.0091 \\
{[1.25]}\end{array}$ & $\begin{array}{l}0.0023 \\
{[0.27]}\end{array}$ & $\begin{array}{l}0.0023 \\
{[0.27]}\end{array}$ \\
\hline Constant & $\begin{array}{l}-0.0768 \\
{[-1.35]}\end{array}$ & $\begin{array}{l}-0.1478 \\
{[-2.92]}\end{array}$ & $\begin{array}{l}-0.0789 \\
{[-1.39]}\end{array}$ & $\begin{array}{l}-0.0912 \\
{[-1.59]}\end{array}$ \\
\hline Number of Observations & 10,929 & 10,929 & 10,929 & 10,929 \\
\hline Adjusted R-squared & 0.476 & 0.438 & 0.476 & 0.476 \\
\hline
\end{tabular}

\footnotetext{
* Observations with greater than the $99^{\text {th }}$ percentile are coded as equal to the $99^{\text {th }}$ percentile.
} 
Table IX

Regression Analyses of Likelihood of Related Spawning

The table presents regressions of the degree of relatedness between a spawning and spawned firm. The sample is derived from public companies listed in Compustat during the period 1986-1999 with patents in either Computer and Communications or Drugs and Medical based on the NBER Patent Citations Data File classification scheme. The dependent variable is the measure of relatedness described in the text. Independent variables include the natural logarithm of inflation-adjusted firm size, the firm's sales growth over the previous three years winsorized at the $99^{\text {th }}$ percentile, Tobin's Q for the firm winsorized at the $99^{\text {th }}$ percentile, dummy variables indicating whether the firm was backed by venture capitalists, dummy variables indicating if the firm was located in Silicon Valley or Massachusetts, and a dummy variable that equals one if the firm reports only one industry segment in Compustat. All regressions include year dummies for each year that the firm is in our sample, though the coefficients are not shown; one includes industry fixed effects. Heteroskedasticity-consistent t-statistics in parentheses adjust for non-independence of observations of the same firm over time.

Dependent Variable: Measure of Relatedness

\begin{tabular}{lcc} 
& Basic Specification & Industry Dummies \\
\hline Independent Variables & $(1)$ & $(2)$ \\
\hline Log of Real Assets & -0.0226 & -0.0151 \\
Mean Winsorized Sales Growth Over & {$[-4.88]$} & {$[-4.41]$} \\
$\quad$ Previous Year & 0.0288 & 0.0183 \\
Mean Winsorized Tobin's Q* & {$[3.44]$} & {$[4.10]$} \\
& 0.0202 & 0.0188 \\
Venture Capital-Backed & {$[2.88]$} & {$[5.10]$} \\
& -0.0467 & -0.0140 \\
Silicon Valley-Based & {$[-2.00]$} & {$[-0.93]$} \\
& -0.0462 & -0.0339 \\
Massachusetts-Based & {$[-2.22]$} & {$[-2.18]$} \\
& -0.0803 & -0.0567 \\
Focused Firm & {$[-2.80]$} & {$[-2.42]$} \\
& 0.0003 & 0.0380 \\
Constant & {$[0.01]$} & {$[2.05]$} \\
& 0.3680 & 0.2993 \\
Number of Observations & {$[5.83]$} & {$[6.59]$} \\
Adjusted R-squared & 844 & 844 \\
Industry Fixed Effects & 0.228 & 0.541 \\
\hline
\end{tabular}

* Observations with greater than the $99^{\text {th }}$ percentile are coded as equal to the $99^{\text {th }}$ percentile. 